\title{
EL PROYECTO POLÍTICO ENSENADISTA EN LA POLÉMICA SOBRE EL DESPOTISMO ILUSTRADO EN ESPAÑA. NOTAS SOBRE EL PROYECTO DE INVESTIGACIÓN "ENSENADA 2002”
}

\author{
José Luis Gómez Urdáñez*
}

\begin{abstract}
RESUMEN: El autor de este trabajo presenta un programa de investigación sobre la política del marqués de la Ensenada.Justifica el empleo del género biográfico como paso previo, ya que el personaje es muy poco conocido y su vida, orígenes, formación cultural, experiencia miitar, etc., influyeron notablemente en su maneras y en su programa politico. Además, se exponen en el artículo algunos puntos del programa ensenadista - se analizan más ampliamente en un próximo libro al que remite el autor-, con el fin de contribuir al conocimiento del "Despotismo Ilustrado" en España. El autor piensa que bubo en efecto programas politicos "ilustrados", como por ejemplo el de Ensenada, y que se intentaron llevar a la práctica en medio de grandes resistencias. En el caso del proyecto ensenadista, fueron menores que las que se verían después. La caída del ministro es la primera demostración de que las políticas reformistas y estatalizadoras impactaban seriamente las estructuras sociales, económicas y políticas del Antiguo Régimen en España.
\end{abstract}

SUMMARY: The autbor of this work presents an investigation programme about the Ensenada's polity. He justifies the neccesity of biography, because Ensenada is a not well-known personage and his life, his origines, bis cultural education, his military experience, etc., bad a notable influence in his way of life and in bis politic programme. Besides, in this article, the author exposes some points of the Ensenada's project summary of the a book that he will publish at an early date-in order to contribute to the "Illustrated Despotism" knowledge in Spain.The bistorian thoughts that there was, in fact, illustrated politic programmes, like for example which had Ensenada, and there was enormous resistances when the some ministers tryed to carry out. In the Ensenada's project case, the resistances were smaller than in the later projects. However, the fall of the Ensenada demostrate that the reformer and state politys had a big impact in the social, economic and politics structures of the XVIIth in Spain.

* Catedrático de Historia Moderna del Dpto. de Ciencias Humanas y Sociales (Universidad de La Rioja). Muchos de los puntos de vista sobre las controversias sobre la biografia los debo a Gracia Gómez Urdáñez, becaria de investigación de la Universidad de Zaragoza, con quien es un placer discutir... de éstas y de otras controversias. En la investigación sobre Ensenada, la ayuda de Noemí Armas, "secretaria de todo", ha sido tan importante como la de su marido, el profesor de la Universidad de La Rioja Santiago Ibáñez Rodríguez. Una vez más, gratis et amore. 


\section{La NeCESidad de EnSENADA: BIografía e Historia}

A la vista de los objetivos y de las reflexiones previas que acompañan a nuestro primer trabajo, El marqués de la Ensenada. El proyecto ilustrado de un déspota, 1743-1754, de próxima publicación, queda claro que el proyecto de investigación que hemos programado no es sólo una biografia. En parte, hemos acudido primero al denostado "género extraordinariamente perecedero", como lo denominaba E. Gallego en $1987^{1}$, por una necesidad comúnmente admitida: la vida, la formación intelectual, la personalidad y las "maneras" del realizador del proyecto político que queríamos analizar eran muy poco conocidas. Pero no era ni lo único que nos atraía ni lo más importante. Antes de nada nos interesó el análisis global de su política, y éste pronto se vio necesitado de argumentos que explicaran la íntima conexión entre el personaje y la práctica, entre el proyecto y las "maneras" con que su autor intentó desarrollarlo y entre esas "maneras" y la coyuntura; en una palabra: entre "biografia" y contexto histórico general.

Trazar los perfiles biográficos de Ensenada no es, pues, una labor ornamental, ni está condicionada por "humanizar" personajes políticos, ni por la "fama" del personaje ${ }^{2}$. No es un fin en sí mismo. El propio desarrollo actual del género biográfico y su profunda renovación epistemológica es una muestra de la superación de las viejas críticas que habían conseguido arrinconarlo en el desván de los útiles más viejos e inservibles del historiador. Ferraroti todavía en 1991 demonizaba la tradición y trazaba una truculenta cadena de consecuencias: la biografía -decía"es una especie de moda pasajera (...) precursora de gravísimos daños por contribuir a la desprofesionalización del trabajo sociológico, la renuncia al análisis como alejamiento del sendero del trabajo científico, el inevitable bundimiento en los pantanos del subjetivismo irresponsable"3. Más ponderadamente, Momigliano proponía una opción ante los riesgos: "peut constituer un instrument de la recherche sociale ou, au contraire, proposer un moyen de la fuir" '. Es evidente que las reiteradas reticencias contra el "género" apuntaban a la biografía tradicional, no a los progresos que estaba haciendo la biografía en las nuevas corrientes historiográficas, que distinguían con claridad las biografías como fin último de la biografía bistórica como instrumento válido5.

1. Gallego, E., 1987. Véase también Bourdieu, P., 1986.

2. En este sentido, la linea "humanizadora" del género biográfico clásico a la manera de un Rodríguez Villa llega hasta prácticamente nuestros días. La búsqueda del "hombre" es un objetivo que puede apreciarse, por ejemplo, en Gómez Molleda, M.D.,1955. Entre las críticas que E. Gallego (1987) desliza contra la biografía clásica no podía faltar la referencia a la elección del personaje biografiado "por fama que inesperadamente se pierde".

3. Ferraroti, F, 1991, pp. 122-123.

4. Cit. en Levi, G., 1989, p. 1.325.

5. Quien más recientemente ha visto el interés de la biografía como herramienta del análisis histórico es quizás C. Forcadell al prologar un magnífico ejemplo de biografia histórica.Véase su "Delantal" en Bonsón Aventín, A., 1994, especialmente pp. 16 y 17. Otra interesante justificación en Bergeron, L. y Chaussinand-Nogaret, G., 1978, I, p.VI, para quienes se trata ante todo de "hacer lo singular plural". 
No sólo en el pasado, también en la actualidad, el "género" en su expresión más tradicional goza de gran predicamento entre una amplia demanda que, cansada de la aridez del texto histórico, busca amenidad y divertimento a través de lo que se sigue considerando "genero de evasión". La industria editorial francesa actual ha devuelto a las biografias ese "privilegiado" lugar, a veces rozando el ridículo, toda vez que alimenta el consumo a base de frivolidades y del vale todo con tal de que sea atrevido y novedoso: "lo nuevo es bueno", el gran lema de la incitación al consumo, ha pasado a la Historia, utilizando sobre todo una de sus más viejas herramientas ${ }^{6}$. ¿Cómo no va a ser un éxito de ventas un libro que ponga en ropas menores a un gran ministro? Pero, de alguna forma, y sin recurrir a los aspectos digamos "morbosos", siempre ha sido así. Tomemos un caso reciente, la biografía de Franco de S.G. Payne (1992), y observemos cómo una suma de banalidades ocupan el mismo lugar que los grandes acontecimientos históricos: "en los cincuenta vestirá trajes de calle bien confeccionados", "su afición por la fabada asturiana" "en sus últimos años desayunaba zumos de frutas, té y tostada", jugaba al golfy un poco al tenis y le gustaba montar a caballo por las mañanas", etc. Algunas de las biografias de los personajes dieciochescos han caído inconscientemente en esos lugares comunes, pero, tratándose del siglo frívolo y libertino, han pasado más desapercibidos. La propensión a buscarle amores al solterón Ensenada, las notas de frugalidad en la mesa que adornan a Campillo o los vicios cortesanos del entorno del "capón" Farinelli, del rey loco y la reina horrorosamente fea son demasiado apetitosos como para que la bistoria basura no los explote.

No obstante, el resurgimiento de la nueva biografía histórica tiene hoy notables soportes epistemológicos y nuevos caminos científicos bastante más tranquilizadores. La conocida polémica mantenida por E.J. Hobsbawm y L. Stone sobre el retorno de la narrativa ha aportado sugerentes reflexiones sobre la forma de concebir la biografía. Para Hobsbawm, sirve para "leer una sociedad" y supera el nada ambicioso proyecto de narrar la vida del individuo. Es una de las maneras de hacer historia, dice Hobsbawm, que "no son un fin en sí mismas" sino que se convierten en "medios de aclarar una cuestión más general, que va mucho más allá de la bistoria particular y de sus personajes". Quizás un buen ejemplo de la interacción de la "historia particular" y la "cuestión más general" sea el de la caída de Ensenada en julio de 1754, uno de los acontecimientos claves para entender no sólamente la trascendencia de la política de Ensenada sino el problema de fondo del despotismo ilustrado español. Sin duda, la gran cuestión es la política internacional, la formulación del poder y su limitación -muy débil para el que podía acumular Ensenada tras la muerte de Carvajal-, la tensión que el exitoso proyecto político ensenadista está produciendo en las éli-

6. Morales Moya ha percibido claramente la relación, sobre todo en Francia, entre el auge de la biografía y la "presión del gran público (...) que incrementa fuertemente su demanda de una bistoria al viejo estilo", Morales Moya, A., 1987, p. 62. 
tes privilegiadas de poder; pero los personajes, la intriga y la pasión asoman detrás. ¿Cómo no reparar en el papel de un Huéscar (luego, Alba) altanero y orgulloso, resentido y aislado del poder que, sin embargo, tenía siempre tan cerca, en las propias habitaciones particulares de un rey vacilante y marginal, incapaz de darle una sola satisfacción? ¿Cómo no ver un En sí nada, un todopoderoso hijo de un hidalgo pobre, que había conseguido todos los resortes del poder, incluso los que sin discusión sólo eran competencia del rey? Un advenedizo, ya abiertamente despreciado - le llaman el gran mogol- y un grande de España, que había llegado a odiarle profundamente, estaban decidiendo, sin embargo, en "la cuestión más general": la política arriesgada con Inglaterra, el catastro y la reforma fiscal, el concordato, las resistencias de los grandes, los nuevos rumbos del comercio y, en fin, lo más molesto y peligroso para la concepción política de los grandes: el robustecimiento del Estado, servido por una clientela creciente de hombres sin brillo social, de parecida extracción a la del propio marqués que había llegado a ser ya "secretario de todo", en palabras del P. Isla. Es evidente que todos estos puntos, muchos de ellos logrados -y exhibidos con petulancia- por Ensenada, algunos con suma perfidia como el Concordato, iban a ser los que permitirían esbozar un modelo de Estado muy diferente al que mantendría la aristocracia durante el resto del siglo ${ }^{7}$. Las sospechas de Ensenada y su comportamiento cuando preveía la amenazadora tormenta que se fraguaba contra él poco un mes antes de su caída permiten que el historiador vea a través de su actitud personal -vigilante, teatralmente estudiada e interpretada: así fue en todo- cómo se precipitaban de golpe los problemas políticos y diplomáticos en una Europa en precario -y fingido- equilibrio y en una España en la que se había llegado a engendrar la sospecha sobre el alcance de las reformas emprendidas por el marqués, sin freno desde que desapareció el grande Carvajal y Lancáster. El gran mogol y sus enemigos por una parte, la crisis política de julio, por otra. Lo singular y particular alumbran sobre lo general y complejo.

Las múltiples opciones de la nueva biografía fueron ya avanzadas por G. Levi, que destacó las múltiples relaciones entre prosopografía y "biographie modale": la biografía y el contexto, la biografía y los casos límite, la biografía y la hermenéutica. Alvarez Junco (1990) las lleva a la política y a la historia total y rotundamente afirma: "la biografía es una de las formas más consagradas y legítimas de hacer Historia". El género, que ya no ha de solicitar perdón, se abre a nuevas modalidades superadoras de la clásica "vida completa": es lo que en Francia se ha bautizado como tranche de la vie. La biografía científica ha de trascender lo individual; lo que realmente adquiere importancia es comprender fenómenos sociales complejos. Es lo que pretendemos al intentar abordar algunas claves del proyecto político ensenadista desde un nuevo uso de la biografía como herramienta. En nuestro caso, como una herramienta más.

7. Cfr. Iglesias, C., 1996, y Rúspoli y Morenés, E., 1996. 


\section{Posición: El Proyecto Ilustrado de un Déspota en la España del XVIII}

Hace unos años J. Fontana, expresándose con la esclarecedora coloquialidad que proporciona el marco de una conferencia, se refería al Despotismo Ilustrado como "algo que no existe". Se basaba en razones "digamos éticas", que pasaba luego a ampliar en el desarrollo de su brillante exposición. Dejaba claro desde el principio que "ningún auténtico ilustrado del siglo XVIII creyó jamás esa patraña de que hubiera 'reyes filósofos' y 'déspotas ilustrados'"; y tomaba de la propia Encyclopédie la definición de despotismo - "gobierno tiránico, arbitrario y absoluto" - y su condena como sistema incompatible con la educación ilustrada. El "despotismo ilustrado" fue inventado a mediados del XIX por los historiadores alemanes a sueldo de la monarquía prusiana con el fin de "embellecer sus orígenes" y difundido por los historiadores franceses, como todo el mundo sabe ${ }^{8}$. En nuestras reflexiones sobre el fenómeno en España mantenemos la misma justificación "embellecedora", si cabe aquí más necesaria a causa de los problemas de homologación europea, de legitimación de la burguesía española y de fundamentación del Estado liberal planteados durante el XIX español, en parte parecidos a los prusianos ${ }^{9}$. Todavía hace unos años, los fastos desplegados con motivo del aniversario de Carlos III se dirigieron intencionadamente a justificar una monarquía "nueva" pero de viejo pasado homologable mediante la reinvención del ilustrado Carlos III y la exaltación del progreso cultural dirigido, que es como finalmente se hacía aparecer la Ilustración dieciochesca de la tópica Segunda Mitad $^{10}$. El recordado y querido Rafael Olaechea ya había dicho con su particular socarronería que Carlos III no sólo no fue un monarca ilustrado, es que además no creyó nunca que lo fuera ${ }^{11}$. No le hacía ninguna falta al rey cazador, del que se dice que, a su vuelta de las actividades cotidianas-misa, confesionario, caza, mucha caza "así cayeran cbuzos de punta"- que le ocupaban todo el día, preguntaba a sus ministros por lo bueno que habían hecho por sus súbditos... durante los breves minutos que duraba la conversación. Sin embargo, parece que no había otro "modelo" presentable entre la realeza española ni otro periodo más civilizado en la historia de España que el carlostercerismo.

Aparte ya de razones "morales" -y presentistas-, Fontana negaba que el despotismo fuese capaz de alcanzar "las cotas de progreso necesarias para sentar las bases de estado moderno que requerían las exigencias de los buenos tiempos": en el plano político, por sus costes de mantenimiento e incapacidad para "rebacer un consenso interno que evitase una quiebra revolucionaria"; y en el plano económico, por no aceptar "las condiciones que exigía el desarrollo

8. Fontana, J., 1989, pp. 125-126. Recientemente, desde otra óptica, Iglesias, C., op. cit.

9. Véase Gómez Urdáñez, J.L., 1996, e p.Algunas reflexiones también en Moreno Fernández, J.R. y Gómez Urdáñez, J.L., 1995 y, sobre todo, en mi prólogo a Alonso Castroviejo, J.J., 1992.

10. Gómez Urdáñez, J.L., 1995.

11. De nuevo, en el marco de una brillante conferencia, luego publicada, Olaechea Albistur, R., 1989 , pp. 52-53. 
capitalista contemporáneo" ${ }^{12}$. En efecto, la capacidad transformadora del despotismo ha sido puesta en cuestión reiteradamente; también, obviamente donde es más clara, en el plano social: como es sabido, al que se ha presentado como el más preclaro rey ilustrado "las desigualdades inherentes a una sociedad dividida por estamentos, clases y privilegios corporativos no le afectaban"13.

Sin embargo, el hecho de que no hubiera reyes déspotas ilustrados no quiere decir que no hubiera ministros con proyectos políticos "ilustrados", es decir reformistas, estatalizadores y modernizadores. Es el caso del de Ensenada. También del de Floridablanca. Como bien dice Roberto Fernández, lo que hizo Floridablanca lo había hecho Ensenada con menos aparato jurídico y legal. Probablemente, también con muchos menos riesgos, en un tiempo de menos crispación ideológica y más confianza popular en la capacidad del Estado por generar fórmulas de renovación, que, en efecto, existieron en el Despotismo Ilustrado español. Se mire por donde se mire, hubo proyecto y se intentó con todo denuedo llevarlo a cabo.

Es cierto, como tantas veces se ha dicho, que la gran preocupación de los déspotas del tiempo de Ensenada era hacer llegar a su mano el dinero necesario para hacer frente a los costes de mantener y consolidar sus Estados en el marco de las grandes potencias embarcadas en una rivalidad permanente; pero, ésta, a mediados de siglo, ya no era sólo "de corona". Precisamente, en muchos casos esa rivalidad afectaba plenamente al propio origen de los fondos que iban a parar a la Hacienda y a los intereses de una clase social en ciernes que no estaba tan muda en España -desde luego, en Inglaterra en absoluto- como se ha pensado. La guerra comercial era ya un hecho: exigía nuevas respuestas técnicas, también más gasto militar ${ }^{14} \mathrm{y}$ un cierto respaldo político acompañado de expectativas de éxito en el marco de la economía; ya no era una guerra más, de prestigios de príncipes y princesas. El proyecto de Ensenada es un claro ejemplo de protección militar a una fuente directa de financiación estatal: los estadistas del XVIII trataban de mantener e incrementar los ingresos procedentes de América, precisamente para hacer frente a la creciente rivalidad militar en el mar que amenazaba con privarles de una fuente segura de dinero, pero el militar y el de la Hacienda no era ya su único interés, al menos no lo fue con Ensenada. Por ejemplo, la operación para monopolizar el comercio del palo de Campeche era una meditada empresa económica, bien programada en costes y beneficios, que unía el interés privado y el público. Los ensenadistas que la diseñan -Banfi, Pérez Delgado, Fernández de Isla- sabían que tendrian apoyo militar contra la presión inglesa. La gran preocupación por el dinero para el Estado estaba atizada después de Aquisgrán por tímidas ideas empresariales que ya superaban la necesidad de recaudar para

12. Fontana, J., 1989 y 1987.

13. Lynch, J., 1991, p. 223.

14. Parker, G., 1988. 
tener al rey rico y contento. Esto lo vio Ensenada, pero no Carvajal, que siguió confiando en modelos de protección directa.

Antes de la paz no hay ningún obstáculo que dificulte observar la obsesión ministerial por los gastos militares. Son esos momentos en que los déspotas no manifiestan que sus desvelos se encaminan al bienestar de sus súbditos; al contrario, entonces gimen con ellos, se conmiseran de la desgracia que supone tener que incrementarles los impuestos. Si piensan en reformar, proyectan sólo medidas de reordenamiento y de eficacia tributaria. Casi la mitad del ministerio de Ensenada, hasta 1749 , discurrió por ese camino. El marqués tuvo que centrarse exclusivamente en las dos ocupaciones -dinero y guerra- que, como el mismo declaraba, constituían el Real Servicio, a la vez que se justificaba con las habituales lamentaciones por las consecuencias sociales derivadas de su propia política. Las medidas que luego justificarían su preocupación por los súbditos esperaron hasta la paz y sólo se mostrarían con la mayor euforia y convicción -en esto el marqués fue un maestro- una vez que los costos militares dejaran de ser acuciantes y la reforma de 1749 -la administración de las rentas provinciales y otras medidas contenidas en los decretos de ese y los sucesivos años- le proporcionara "milagrosamente" dinero. Goubert (1979)" ha señalado que las tropas asoman siempre detrás de este Estado benéfico y paternalista, mientras la guerra consume los esfuerzos y produce un despilfarro de las posibilidades. Pero, en el XVIII no sólo hubo muchos periodos de paz sino que la guerra había cambiado: "guerra sorda" llamaba Carvajal, un tanto desesperado porque no triunfaban sus ideas utópicas de paz, a los episodios de "guerra comercial" en el Atlántico, que Ensenada veía ya con toda naturalidad, sin lamentos, porque ya no afectaba más que a una remota periferia y, además, le permitía dinamizar sectores básicos de la economía productiva desde abajo y hacer demostraciones con destino a la diplomacia y la escena internacional.

Domínguez Ortiz hizo notar que "pocas reformas son factibles cuando todos los recursos son absorbidos por las atenciones militares". Sin embargo, también reparó en que "la guerra se babía convertido en una carga ordinaria, no mas pesada que las posteriores paces armadas, y la economía europea del siglo XVIII se mostró capaz de soportarla". En efecto, la guerra se había tecnificado, la población civil la sufría menos, los escenarios se alejaban de Europa y las nuevas técnicas imponían otras estrategias que los terribles asedios, incendios y saqueos de poblaciones. Pero, el gran historiador hace referencia a las "paces armadas", también costosas. De nuevo, Ensenada es un buen ejemplo. La otra mitad de su ministerio, la que se desarrolla en el periodo de la paz fernandina,

15. La tesis es muy matizable en España. El XVII no presenta las cotas de malestar y revuelta producidas en Francia, ni el XVIII permite ver una latencia revolucionaria. No hay prácticamente motines, como ha señalado Laura Rodríguez (1975). De gran interés sobre los conflictos sociales en Castilla en los siglos XVI y XVII, con un punto de vista muy distante de los tópicos de la moral, el estómago y el temor a la represión, véase Lorenzo Cadarso, P., 1996. 
pudo ser un respiro, pero inmediatamente comenzó el rearme, el desarrollo de una política naval y armamentista ambiciosa. Como es sabido el marqués pensaba en la próxima guerra, sabía que Inglaterra sería el enemigo y el mar el escenario. "Busco dinero y fuerzas de mar y tierra", le decía a su amigo el cardenal Valenti ${ }^{16}$. Sólo que la "paz armada" ensenadista se mostró un eficaz medio de desarrollo interior y de estímulo a los intereses comerciales públicos y privados.

Inglaterra estaba volcada al comercio marítimo y Ensenada sabía que seguiría ampliándolo a costa de las Indias que él debía proteger. Conocía la constancia de gobierno inglés en la presión diplomática para arrancar "derechos" y la protección estatal que necesariamente debía dispensar a los comerciantes. Wall, desde la embajada en Londres, se lo había dicho de mil maneras. "Sus colonias, estas son sus riquezas, sus tesoros y sus minas, éste es el verdadero y único interés ingles y por él han becho tantas veces la guerra y endeudado a la nación"17. Tanto a Carvajal como al propio Ensenada, Wall les daba cuenta desde su privilegiado observatorio londinense del valor de la opinión pública, de la capacidad de presión de los comerciantes sobre el gobierno y de la atención que los partidos, igual el del gobierno que el de la oposición, prestaban a los asuntos coloniales para no exponerse a perder las elecciones. La revolución parlamentaria había conseguido controlar el poder del soberano precisamente en el terreno clave de los ingresos y la dirección del gasto, a la vez que impulsaba las primeras reformas sociales y económicas en la propiedad, la industria y el comercio. Pronto se pudo ver aquí con más claridad que en el continente que la riqueza del Estado dependía de la riqueza de los súbditos -en definitiva, lo que desarrollaría luego Adam Smith-, pero, sobre todo, que la riqueza dependía en último término de las diferentes políticas, y la que venía de las colonias, de la protección militar que los gobiernos estuvieran dispuestos a proporcionar. La gran preocupación de Wall era que la oposición y el gobierno coincidían en la política comercial exterior con los intereses agresivos de los comerciantes y que el gobierno nunca escatimaba protección militar y económica aún a los actos que desesperaban a Carvajal que los creía pura piratería. El embajador le había dicho a Ensenada un año después de la paz de Aquisgrán que "el grito de toda la nación inglesa" era "siempre guerra" y el esgrimido contra Walpole "no visita, tomar y guardar"18. Pero Wall veía también que los comerciantes no ponían obstáculos a contribuir directamente a armar al estado con dinero, pues confiaban en que su destino era la armada que necesitaban.

Esta es la gran diferencia con las naciones continentales, en las que el absolutismo mantenía con plena rigidez el poder ilimitado del soberano, amparado por los privilegiados. Las estructuras sociales emanadas del privilegio contenían

16. AHN, Estado, leg. 2850, Ensenada a Valenti, 6 de octubre de 1750.

17. AHN, Estado, leg. 4277-2, Wall a Carvajal, 20 de setiembre de 1753.

18. AHN, Estado, leg. 4277-2, Wall a Ensenada, 8 de setiembre de 1749. 
en sí mismas la autolimitación fiscal: aquí el gran bien seguía siendo la tierra, pero precisamente los propietarios estaban en buena parte exentos de tributar, mientras el peso recaía en el campesinado. El Estado no podía incrementar su disponibilidad sin tocar los privilegios. Las reformas sólo pretendían robustecer su estructura y aumentar su capacidad para estimular los sectores económicos que el tiempo declaraba como los nuevos pilares fundamentales del progreso. Pero Ensenada había visto el problema con claridad: B. Keene, el embajador inglés, decía de él que quería ante todo hacer de su rey un comerciante. El problema de desarrollar el comercio ultramarino exigía reformas -tanto Carvajal como Ensenada y Wall llegaron a vislumbrar la proximidad de la libertad de comercio-, pero, sobre todo, un plan estatal de protección, para el que hacía falta dinero: lo que buscaba Ensenada en medio de las conocidas limitaciones que él logró burlar en parte acudiendo a una filosofía política ciertamente ajena en España, algo muy parecido al denostado despotismo.

A ese denigrante e impronunciable término, el gran pecado en política por ir unido a la "razón de Estado" que el catolicismo no podía tolerar, se refería Carvajal cuando decía que le desesperaba lo que hacía Ensenada, sus "machiaveladas", sus "artes", su perfidia -la crueldad con que logró acabar con Macanaz-; pero, Ensenada no tenía inconveniente en decirle al cardenal Valenti: "la cuestión se ba reducido a pura razón de Estado, de que es Vuestra Eminencia. maestro consumado, y a politica; pero inseparable uno y otro de lo más elevado y serio que es la religión, por las contingencias"19. "Razón de estado", "política" y "religión por las contingencias": he ahí la nueva práctica, el nuevo sistema que el marqués podía hacer ya explícito a sus íntimos -con Valenti mediaba incluso una fuerte suma por medio- tras diez años de ministerio: en este caso, nada menos que al cardenal secretario de Estado del Vaticano, al que llamaba "maestro consumado". El término despotismo era en efecto impronunciable, pero no impracticable.

Los ministros tuvieron siempre presente la autolimitación hacendística hasta bastante después de Ensenada; sabían, como el propio marqués, que sus proyectos de reforma no podían actuar directamente contra el principal fundamento del orden establecido, aunque supieran que era el principal obstáculo de su propia actuación y del éxito que requerían para sus proyectos. Sin embargo, conforme avanzaba el siglo, las voces críticas erosionaban paulatinamente el sistema. Ensenada repetía constantemente que España era rica y que era posible incrementar los ingresos de la Hacienda; también llegó a pensar que la opulencia del Estado dependía de la riqueza de los súbditos, que sólo si eran ricos podrían contribuir más. Pero percibió claramente los riesgos. Aquí no había habido una revolución que hiciera depender las decisiones políticas de la opinión pública de

19. AHN, Estado, leg. 2850, Ensenada a Valenti, 14 de julio de 1750 . Sobre el caso Noris, al que Ensenada se refiere, véase el excelente artículo de Olaechea, R., 1981. 
comerciantes, armadores navales, capitalistas, como Wall le decía permanentemente que ocurría en Londres. Ensenada sólo podría intentar lo que era más fácil de resolver sin riesgos: el desorden fiscal y la falta de eficacia recaudadora. A eso dirigió sus primeras reformas en cuanto la paz le permitió un mínimo sosiego.

El reformismo de Ensenada inauguró una vía cargada de futuro, pero también de riesgos, para lo que quedaba de siglo: las reformas, impulsadas por la necesidad de refuerzo estatal antes que por las convicciones "sociales", se dirigirían a los flancos más débiles del sistema: en principio, a los intermediarios que el propio régimen había creado. El marqués las empezó con dos medidas: el aumento de competencias de los intendentes y del personal al servicio del Estado, y la administración directa de las rentas provinciales. La primera era un efecto de una idea que desde Colbert estaba presente en las cabezas de los déspotas europeos sin excepción; la segunda suponía un ataque a los arrendadores y a sus redes con total garantía de éxito: la debilidad de estos gorriones era evidente después de las constantes críticas que despertaba su actuación, generalmente condenada por todos los sectores sociales ${ }^{20}$. Ensenada empezó pues por el lado más fácil -así harían también sus sucesores- pero descubrió quizás con sorpresa que los resultados superaban las más optimistas previsiones. En efecto, la sola desaparición del intermediario produjo un aumento de los ingresos que desató la primera euforia del marqués. Había sido fácil y muy productivo ${ }^{21}$. Nuevas medidas sobre otras rentas siguieron a las de la administración directa y aún otros proyectos de rentabilidad también previsible, como el del Giro Real. Otra vez Ensenada podía comprobar que era posible limpiar el sistema por sus bordes sin asomarse al interior.

El proyecto del Catastro, que es el que más controversias sigue despertando, se inscribe en un primer momento en ese escenario de reforma de la administración para incrementar su eficacia. Sin embargo, en su larga duración, evolucionó hasta llegar a rozar las estructuras más sólidas de la sociedad del Antiguo Régimen. En una primera fase fue, en efecto, un intento de reforma administrativa, muy influida por las frecuentes manifestaciones que relacionaban la prosperidad de Cataluña con la aplicación del sistema catastral. Pero, el marqués se tomaba siempre mucho tiempo y era en todo un perfeccionista interesado por fundamentar sus proyectos con una información exhaustiva y con pretensiones de exactitud, en la mejor línea de la práctica política del despotismo europeo; ya desde la prueba de Guadalajara amplió la base de datos y, a pesar de la oposición, ordenó anotar las medidas de las propiedades. Probablemente, la segunda fase se inició cuando la junta creada al efecto manifestó su cerrada oposición al proyecto, aduciendo entre muchos motivos el problema que planteaban la propie-

20. Vid. en Gómez Urdáñez, J.L. (1996, e.p.) las opiniones de los contemporáneos en Zavala Y Auñón, M., «Representación al Rey N. Señor D. Fhelipe V (que Dios guarde) dirigida al mas seguro aumento del Real Erario... K.S.L. 1732». Miscelánea Económico-política o Discursos varios sobre el modo de aliviar los vasallos con aumento del Real Erario. Pamplona, 1749.

21. García-Lombardero, J., 1978. 
dad y las rentas eclesiásticas. Pero, Ensenada estaba en un momento óptimo para mostrar sus poderes: Sánchez de Valencia, su principal colaborador, se arredró y hasta pensó en abandonar; sin embargo, el marqués sacó adelante el proyecto recurriendo a sus bechuras entre altos mandos del ejército, que tanto conocía y en el que le estimaban. El celebre decreto pasó rápidamente a la firma del rey: Ensenada aumentaba su euforia ${ }^{22}$.

Durante esta fase, algunos de los problemas manifestados por la Junta se demostraron reales: los costes, la diversidad de medidas, la ingente masa de documentación que iba llegando, la oposición que despertaban las operaciones en algunas zonas... El marqués pudo darse cuenta de que iba a ser muy difícil aplicar luego la Única Contribución. Quizás su interés por los efectos sobre el pretendido incremento de recaudación pudo disminuir; al menos ya no era algo tan urgente como al principio, cuando realmente temía por el déficit: ahora, Ensenada tenía dinero, como él mismo decía orgulloso: las rentas directamente administradas, la restauración e incremento del tráfico ultramarino y los sorprendentes beneficios que estaba obteniendo del Giro Real -claramente una caja $B$ de la que disponía sin más intermediarios que sus más próximas becburas- le permitían mantener el proyecto de catastrar a pesar de todo. Había dos razones poderosas: una, que el déspota no puede dar su brazo a torcer: él mismo lo dice; dos, que a largo plazo la información que está obteniendo tendrá utilidad. Su enorme curiosidad por conocer y manejar información debió influir ahora, pero, creemos que el solo hecho de tener en los papeles la información exhaustiva sobre la propiedad y rentas de la Iglesia en el momento en que estaba negociando con Valenti y Ventura Figueroa el Concordato con Roma aumentó su interés por la información y, sobre todo, le permitió ver cómo aumentaba el control estatal. Una de las primeras medidas que emanan del concordato de 1753 es precisamente la realización de una amplia encuesta sobre la riqueza de la Iglesia española y una de las primeras realizaciones, el incremento de la contribución de la Iglesia al Estado.

El problema de la contribución de los eclesiásticos al Estado estaba planteado desde hacía tiempo, pero se mantenía dentro del embrollo jurídico, al que, si cabe, el concordato de 1737 había contribuido todavía más. Mientras siguiera así, sin desentrañar la maraña económica, no habría forma de reglar porcentajes o de calcular cupos. Cualquier intento de hacerlo tropezaría con la variedad de justificaciones eclesiásticas habituales y finalmente con el poder de la Iglesia. A diferencia de Campomanes o Godoy, Ensenada no podía en su tiempo ni soñar con que la Iglesia era la parte más débil, como se ha dicho. Campomanes tenía más preparación jurídica, Godoy más necesidad; uno y otro contaban además con dos

22. Aparte del ya clásico Matilla Tascón, y nuestro trabajo sobre Ensenada, tiene gran interés Camarero Bullón, C., 1989, en donde además del análisis de los datos del catastro hay una excelente descripción del proceso político que sufrió el proyecto. 
hechos previos: Campomanes, con la expulsión de los jesuitas y una primera venta de bienes que resultó: no había miedo; Godoy, con la crítica generalizada en medio de la crisis y con el conocimiento mucho más certero sobre la riqueza eclesiástica y sus fundamentos, ya más débiles sin duda. Pero, Ensenada partía de la nada; sólo tenía intuición y una enorme confianza en su poder; además, mantenía buenas relaciones con los jesuitas -el formidable grupo de presión bajo cuyo manto se protegía (y no al contrario)-, y era capaz de llegar directamente al Papa, como lo hizo para sacar adelante el concordato. Su proyecto era de vía lenta como todo. No había prisa, sino necesidad de dar pasos seguros. Todavía la tormenta ideológica sólo se atisbaba. Voces tan terribles como la de Luis de Flandes, que escribía "contra el moderno" en todas sus variantes, "escéptico o dudoso, rígido o moderado", no eran todavía más que profecías en la mejor linea de los predicadores milenaristas :

"Mucho hay que recelar que el infierno, inventor en cada siglo de una máquina heretical, no venga armado en éste con la novedad de sus voces, para abrirles poco a poco brecha y asaltar a su tiempo la santa fe católica (...) error que los reverendos padres teólogos de Inquisición creo tendrán muy presente" ${ }^{23}$.

Todavía la reacción contra las reformas permaneció un tanto adormecida, y así lo quería Ensenada, que en sus cartas a Valenti le manifestaba constantemente el tacto que empleaba para no despertarla. El caso de las obras de Noris pone de manifiesto que en 1750 , en las alturas del poder, se iba a lo práctico y se evitaba el enfrentamiento ideológico: "si las obras de Noris corriesen en España se levantaría un cisma en las universidades que alborotaría todo el reino", le dice Ensenada al cardenal Valenti, pero unos meses antes, le confesaba: "Para mi es indiferente que corra o no corra la probibición de las obras de Noris, pues busco dinero y fuerzas de mar y tierra y no teologías" ${ }^{24}$.

A pesar de las críticas y las resistencias, las propiedades de la Iglesia serían catastradas, como las de la nobleza. Por primera vez, se obligaba a los privilegiados a pasar por el papel, a justificar rentas y propiedades, a poner la maraña de su poder económico a la vista de un Estado llamado a ser todopoderoso. Pero no había urgencia, como ocurrirá después. Ensenada tiene dinero y eso le hace ser todavía más paciente: no hay ni siquiera un atisbo de reforma social: sus "deseos" empiezan y acaban en la maquinaria del Estado.

Entre 1750 y 1752 empieza a estar satisfecho de sí mismo y se pavonea como nunca.Tiene dinero y supera a Carvajal, el noble, el jusrista de sólida formación universitaria, que ve con temor los riegos de sus proyectos. El marqués, que desprecia a los legistas universitarios, a los doctos inútiles, incapaces de sacar pro-

23. Flandes, L. de, El antiguo académico contra el moderno escéptico o dudoso, rígido o moderado. Defensa de las ciencias y especialmente de la física pitagórica y médica en el conocimiento y práctica de los médicos sabios. Madrid, sin fecha, pero de 1742-44, t. I, pp. 161-162.

24. AHN, Estado, leg. 2850. Ensenada a Valenti, 6 de octubre y s.f., pero de 2 de junio, de 1750. 
yectos adelante, paralizados en ridículas discusiones, puede manifestar su satisfacción personal: él, que no ha pasado por la universidad ni ha recibido educación alguna que no sea la que le dio el ejército, como confiesa reiteradamente (con el fin de lograr mayores elogios). En 1749, despreciaba los dictámenes sobre los juros de muchos consejeros: "la respuesta de Castillo y Cañaveras es lastimosa (...) Paréceme disparate"25. Unos años después, tras la firma del Concordato, se explaya: "yo logro lo que be aspirado, que es a bacer ver a estos legales y sus secuaces que sin el estudio de las leyes se bacen y discurren grandes cosas, y a mis émulos, que en lo que les parecía se ba perdido tiempo se ba ganado'"6.

Ensenada tiene la plena confianza de los reyes, de la corte, en la que se mueve como pez en el agua: sigue comprando relojes para el rey, partituras y claves para la reina, les distrae con su carácter jovial y mundano, les monta la escuadra del Tajo, en la que con su disfraz de almirante se codea con los grandes... desde arriba; mientras el huraño Carvajal, al que los festivales del poder le desesperan, ve fracasar su "lancilla", el fiel de la balanza, que quería que fuera España a costa de presentarse neutral en el tenso escenario atlántico. El "Tío no hay tal" -así le llamaban, sin duda, porque él utilizaba frecuentemente esta frase en sus tajantes negativas- seguía pensando ingenuamente en el símil de la balanza, en la que un platillo era Francia y otro Inglaterra, solicitando"una mano por la parte superior que afiance la lancilla que está en medio; en parando ésta, contenerla firme; cesó la colusión y movimiento y queda la balanza en fiel y el peso en permanente quietud"27. Para lograr ese papel para España llegaba a proponer a Huéscar puerilidades de esta guisa: "no bay otro partido que tomar que mostrarnos como vencidos, de que no podemos competir por mar, para que crean (los ingleses) que no les queda qué vencer"ns.

Los ambiciosos proyectos del marqués en la Marina, su concepción de "paz armada", ya se podían exhibir en 1752. Ensenada había conseguido resolver uno de sus mayores problemas: tenía dinero. "porque el fundamento de todo es el dinero"29, le había dicho al rey. El mismo se sorprendía de tener fondos en 1751: "ni sé como los bubo, ni como los bay abora para lo necesario"3o, decía, a la vez que confesaba una vez más que no entendía nada de Hacienda. Sin embargo, la compra de maderas para hacer barcos, el ritmo de construcción en los arsenales, los contratos de técnicos extranjeros de las más variadas artes marineras y artilleras, las levas militares de gitanos y vagos demostraban que el pro-

25. AHN, Estado, leg. 2958, billete de Ensenada, sin fecha ni firma, pero de 1749.

26. AHN, Estado, leg. 2850, Ensenada a Valenti, 31 de enero de 1753.

27. Carvajal, Mis pensamientos. BN, mss., 10687.

28. AHN, Estado, leg. 4166. Carvajal a Huéscar, 13 de diciembre de 1747 . Lo realmente sorprendente es que Carvajal creyera poder engañar así a los ingleses.

29. Representación... 1751.

30. Representación... 1751. 
yecto daba resultados. En 1752 las demostraciones de la Marina ya intranquilizaban a Keene: Ensenada hacía las primeras exhibiciones de fuerza en las Antillas. Carvajal se mostraba temeroso - "la tempestad va a romper" le dice a Wall- y desconfiaba abiertamente del marqués, que ya sabía que le ocultaba información: España mantenía la paz -hacia afuera, la "paz astuta" (no tanto) del iluso Carvajal- pero, en realidad estaba en pleno rearme naval, el que Ensenada había planificado para ocho años y que, desde el principio, intranquilizó a Carvajal:

"Hácese bulla -le decía Carvajal a Huéscar- de hacer navíos e introducir comercios (sin conocimiento) y yo persuado lo contrario: que se esté el ejército a ver si nos dan la posesión, que nada se reforme, sí sólo no recluten por el ahorro, y que hagamos que no podemos y que es preciso sujetarnos" ${ }^{31}$.

El desarrollo naval era un motor de incentivación interior y a la vez consolidaba el futuro de América: los recursos que ahora se invertían aseguraban el futuro de la monarquía. Si se mantenía América y se incrementaba su rentabilidad, bastaba con que el Estado siguiera absorbiendo sólo una parte de las rentas de los privilegiados; no había todavía necesidad de tocar sus bienes, ni de cuestionar la amortización. El proyecto ensenadista era ante todo un sistema "conservador" y, en realidad, poco arriesgado en las cuestiones interiores. Sin embargo, y a pesar de que sólo rozó los límites del sistema, fue arrumbado. Probablemente, en este primer fracaso del reformismo haya que buscar el antecedente directo de las contradicciones del "despotismo ilustrado" español en la segunda mitad del siglo.

\section{Situación del Proyecto de Investigación}

La selección de documentos que hizo Antonio Rodríguez Villa en su biografía de Ensenada está guiada por el interés de justificar la grandeza histórica del personaje y su papel de brillante estadista. No obstante, el corpus documental contiene gran parte de los escritos políticos de Ensenada y muchos documentos de gran importancia sobre su actividad pública y, en menor medida, privada. La mayor parte de los estudios inmediatamente posteriores añadieron poco a ese "corpus" inicial y normalmente no cuestionaron la selección. Más que estudios históricos eran discursos de ocasión, de políticos, marinos y publicistas, generalmente conservadores, que hagiografiaban al marqués proponiéndolo como modelo. Sólo cuando el interés de los historiadores derivó hacia aspectos parciales aparecieron algunos documentos que ampliaban el monto inicial. Así, Fernández Duro, Angela Rives, R. Bouvier o J.F. Guillén ${ }^{32}$, aumentaron lo que se conocía con

31. En Ozanam, D., 1975, p. 357.

32. Incorporamos al final una amplia selección bibliográfica bajo el epígrafe Breve Guía Bibliográfica del Proyecto, a la que, con el fin de evitar referencias al pie excesivamente prolijas, remitimos desde ahora. 
documentación relativa a la Marina, la corte, las relaciones hispanofrancesas o la protección a las ciencias dispensada por Ensenada en las figuras de Ulloa y Juan, respectivamente. Sin embargo, la biografia de Ensenada no ganaba en profundidad sino en extensión.

El trabajo de M.D. Gómez Molleda sobre la correspondencia íntima del marqués aportó una fuente de extraordinaria importancia, el archivo de los duques de Alba, sobre la que ya había una selección sobre Huéscar (luego Alba) realizada en el propio seno de la casa. Poco después, la misma autora ampliaba las fuentes de sus trabajos, pero éstos ya no se dedican tanto al marqués como a las relaciones internacionales, a Carvajal, a Macanaz, etc. Con todo, Ensenada sigue siendo una referencia permanente y los documentos que hacen referencia a su política proceden ya de otros ámbitos nacionales y, más importante, internacionales.

Poco después, Ozanam publica la correspondencia de Carvajal y Huéscar, con una excelente introducción. Ensenada vuelve a aparecer constantemente en la relación entre los personajes, que, desgraciadamente, acaba en la obra de Ozanam en 1749. El mismo autor había publicado en 1960 en la colección Recueil des instructions interesantes documentos sobre el problema de las relaciones con Francia, en las que Ensenada volvía a ser abordado en cuanto a sus relaciones con los embajadores franceses. Volverá sobre el tema en varias publicaciones posteriores. En 1980 publica una representación de Ensenada, la de 1751, con un interesante aparato crítico. Pero, además, es muy importante la labor de Ozanam porque inicia los primeros problemas de la crítica de los textos aportados por Rodríguez Villa. Así Ozanam aprecia que la célebre Representación de 1751 que transcribió el archivero no está completa; probablemente vio otro documento que el que transcribe Ozanam que descubre también un posible error de atribución de un documento de gran importancia que Rodríguez Villa propone como de Ensenada. Para Ozanam, "la minuta del documento es autógrafa del oficial mayor de Estado Montiano". En nuestro trabajo mantenemos, abriendo el paso a la duda y a la necesidad de profundizar en la investigación, que esa "Idea de lo que parece preciso en el día..." como documento destinado al rey, está por encima de las posibilidades de un oficial mayor, y que Montiano pudo escribir por encargo o copiar luego el documento; con todo, lo importante es que en todo caso el documento no parece sólo de Ensenada, sino más bien del entorno que se está creando con Carvajal en el centro, al que el marqués se adhiere. Habitualmente Ensenada no descubría sus intenciones en política exterior, aparentando que eso era de Estado y, siempre que se refería por necesidad al juego de alianzas, se mostraba más cauto. La frase "lo que importa es la paz y que se balancee el poder de la Francia, estableciendo nuestra unión con los ingleses y austríacos..." es difícilmente atribuible a Ensenada, aunque en este documento pudo terciar -es seguro que se había ganado la confianza de Montiano- para desmarcarse del grupo de Villarias y tranquilizar a la reina Bárbara. Durante los primeros meses del reinado de 
Fernando VI, se produce un momento apasionante pero poco claro en lo que respecta a la actuación de Ensenada, que estuvo en el punto de mira de la nueva corte por su anterior conexión con los del palacio de los Afligidos, los agrupados en torno a la reina viuda, la Farnesio. Su acercamiento a Carvajal, facilitado por la relación con su joven amigo Huéscar, era la única vía que le quedaba a Ensenada en un momento en que la reina se había entregado a la "sangre portuguesa" del prudente y bienintencionado Carvajal y sospechaba de todos los cortesanos del anterior reinado, en el que, sin duda, le habían hecho la vida imposible a ella y a su pobre marido.

Nuevas fuentes son incorporadas en los últimos años a otros aspectos claves de la política ensenadista: las que informan de su interés por el progreso científico y su obra en la Marina y las que descubren sus manejos en el concordato y en otros problemas de la política eclesiástica, quizás sean las más interesantes. Merino Navarro y Horacio Capel han contribuido a ampliar lo que sabíamos por Fernández Duro y por J.F. Guillén; el primero, mediante la ampliación de documentos, sobre todo los procedentes de AGS, ha logrado documentar la obra de Ensenada en la Marina desde variados puntos de vista, entre los que destacan los relativos a la técnica y a la preocupación por la infraestructura de la construcción naval. Horacio Capel ha logrado fundamentar el interés ensenadista por el soporte técnico de sus proyectos mediante la incorporación de argumentos de carácter global al debate sobre la ciencia y la técnica en España y al papel del dirigismo estatal en su promoción.

Sobre el concordato y la política eclesiástica, la obra de Rafael Olaechea es la más sólida contribución. El admirable profesor de la Universidad de Zaragoza descubrió como nadie las "artes" del marqués en su negociación con Roma y supo argumentar el problema ideológico del regalismo a lo largo del siglo, fijando con precisión sus limitaciones y sus contradicciones. Incorporó fuentes muy variadas, entre ellas las procedentes de los archivos vaticanos, y llevó magistralmente la ironía, también la pasión, a la polémica sobre la Iglesia española del XVIII y el despotismo ilustrado, a la que contribuyó con puntos de vista muy críticos. En lo relativo a Ensenada, quizás sus grandes aciertos fueron descubrir la fuerza de la clientela ensenadista, lo que llamó el partido ensenadista, y ponderar el apoyo de Ensenada en el cuerpo jesuítico en sus relaciones políticas. No hay duda de que a Olaechea el estudio del reinado de Fernando VI le sirvió mucho para ser tan perspicaz al estudiar al conde de Aranda y para afinar la crítica contra los tópicos de la segunda mitad y el carlostercerismo en boga.

Hay, además, algunas contribuciones recientes que, centradas en problemas de carácter general -las relaciones internacionales de España, el tráfico comercial con América, etc., la fiscalidad- han aportado nuevas vías de interpretación de la política ensenadista. Recientemente, han aparecido trabajos que incorporan fuentes biográficas, que, sin tener gran interés para lo que realmente nos preocupa, merecen ser conocidas. Los archivos parroquiales de Hervías y Alesanco 
(La Rioja) fueron explotados por F. Abad (1985) en busca del verdadero lugar de origen de Zenón de Somodevilla. Dio con él -sin duda, Hervías-, pero sólo resolvió a medias el problema de la doble partida de bautismo, cuya solución no es otra que el interés por la familia Somodevilla de ver reconocidos los privilegios de un hidalgo "dudoso" en la pila del pueblo en que más fácilmente habían arraigado. El artículo de R. Valle (1985), en el más puro genealogismo, no aporta mucho más sobre esta cuestión. En nuestro trabajo, hemos utilizado estas fuentes, pero también otras, posteriores -las pruebas de calatravo, etc.-, en que las mentiras del propio marqués - por ejemplo, la atribución de su hidalguía al Solar de Valdeosera- dejan al descubierto su dudosa hidalguía de remotos orígenes "vizcaínos".

Más interés tienen los dos archivos privados que F. Abad pudo ver, el que guardan dos familias, una de la localidad navarra de Corella y otra, de la riojanoalavesa de Laguardia. Los dos archivos tienen interés porque aportan relaciones de Ensenada con personajes de su tierra -aunque, al parecer, escasas-, como el marqués de Someruelos y unos militares que estaban en Cádiz cuando el marqués estuvo desterrado en el Puerto de Santa María, cuya correspondencia, utilizada por Abad, hemos empleado también.

Nuestro trabajo incorpora fuentes sobre todo de AGS y AHN seleccionadas ${ }^{33}$ desde el punto de vista de la reconstrucción histórica general. Más que sumar puntos de interés en la figura y la obra de Ensenada, lo que nos interesaba era reconstruir su proyecto y relacionar sus preocupaciones, sus ideas y sus realizaciones como un todo a entender en su expresión global. La gran preocupación fue dilucidar si había un verdadero proyecto político. Con todo, aportamos algunas fuentes nuevas, y pronto se despertó el interés por el final del ministerio y la caída, quizás el periodo menos estudiado y que, sin embargo, iba apareciendo como una fase en la que el pensamiento de Ensenada se muestra mucho más elaborado y su política más documentada. La caída demostraba que había una crisis latente, que precipitaría en junio-julio de 1754 , ligada a la política exterior, pero que sería sencillo para los ejecutores del plan enlazar con los problemas interiores, una de sus primeras preocupaciones después de conseguida la caída de Ensenada mediante argumentos de procedencia exterior. Había al menos dos elementos importantes: el poder despótico de Ensenada y su asunción de hecho al primer ministerio en un régimen todavía aferrado a la polisinodia absolutista española cuando muere Carvajal, de lo que ya hemos hablado; pero, también otro argumento de gran interés: la nítida manifestación de lo que, con toda prudencia, denominamos "partido" ensenadista. Probablemente, el éxito de Ensenada se debe al despliegue de una clientela de nuevo cuño, no una red politique a la manera clásica. El "partido" se muestra como un crisol en el que confluyen hombres de eficacia, técnicos y científicos, leales servidores; un nuevo mundo de

33. Véase el apartado de fuentes consultadas en Gómez Urdáñez, J.L., 1996, e.p. 
criados del Estado (ya no tanto de la Corona) con conciencia de servir a las ideas de su máxima figura política. Porque, finalmente, donde se demuestra el progreso del poder ministerial es precisamente al final del ministerio, cuando el "partido" es evidente y todo el mundo habla de él: un poder que escapaba de las limitaciones y de la compartimentación, un poder cuasiautónomo que confundía secretarías y consejos en función del éxito mediante cualquier medio y mediante la utilización de sus leales antes que de las instituciones. Así se había visto ya en la imposición del Catastro, cuando recurrió a la Junta de militares; en el tratado de Límites, que claramente había intentado paralizar; en la política marítima con Inglaterra, en la que ladeaba a Carvajal; en el Concordato, en cuya negociación no es ya que Estado y Gracia y Justicia no mediaran, sino que ni siquiera se enteraron; en la administración del Real Giro, excesivamente "autónoma". A la muerte de Carvajal, la sombra de la reina viuda se agiganta y Carlos III se ve más deseado que nunca en el secreto de algunos ensenadistas que probablemente van más allá que el propio marqués aunque sea en tertulias y mentideros. El miedo saca a relucir un Ensenada conspirador ${ }^{34}$, nada menos que en las cercanías de los tronos de los hermanos. Era evidente que un hombre capaz de desplegar ese poder "despótico" debía ser eliminado de la escena política española.

Hemos utilizado para este periodo sobre todo la correspondencia de Abreu, el sucesor en Londres de Wall, del embajador en París, Masones de Lima, y otros embajadores, así como la correspondencia de Valenti y algunos papeles de los muchos que sobre el tratado Límites se conservan en AGS, y otras correspondencias transcritas conocidas -la de Keene, la de Rávago (a reparar sobre la reciente obra sobre el confesor que estamos consultando), etc.-; pero, es necesario explotar sistemáticamente la correspondencia y los papeles de Keene,tanto los conservada en AHN como los de los archivos británicos, la de Duras, abundante en los archivos franceses, y la de Huéscar, en el Archivo de la Casa de Alba. Las tres piezas son fundamentales para profundizar en el conocimiento del escenario de la crisis de 1754 y de sus antecedentes políticos.

Además de las fuentes que hemos empleado con mayor o menor exhaustividad, hay algunas localizadas que a lo largo del proyecto deben ser explotadas para sostener o enmendar esas primeras reflexiones. En primer lugar, vamos a proceder a la crítica de los documentos transcritos por Rodríguez Villa. Algunos no están completos, como ya hemos dicho, pero, hay otros que el archivero no transcribió a propósito; por ejemplo, el propio inventario de bienes del marqués confeccionado por orden de Wall, un inventario vengativo si duda, que descubre la riqueza del marqués y que a Rodríguez Villa le debió parecer contraproducente para su intención reivindicadora de un "honesto patriota". Es necesario analizar los documentos de AHN sobre este inventario, que contienen

34. Véase en ibid. la actuación de Masones de Lima en París y su delación mediante carta a Wall de una presunta conspiración napolitana. 
valiosa información que nosotros sólo hemos utilizado en parte. No hemos entrado sino someramente en la valoración de las riquezas del marqués, que definen la dirección de su ambición hacia la acumulación de joyas y dinero a la manera de los grandes ministros franceses ${ }^{35}$, y en la justificación del propio Ensenada que declara que sus riquezas provienen de sus sueldos y de los "obsequios" del rey. Pero, no debía ser sólo eso: la declaración de Banfi muestra que había otros "obsequios" que los que salían de la mano real, ya que, según dice, Ensenada le había hecho admitir unos regalos del virrey del Perú cuyo valor ascendía a 67.000 reales. El inventario de Ensenada se realizó con la ayuda de un platero que tasó las joyas en su valor. La suma es enorme, aunque el total puede variar bastante, una vez que se analicen en profundidad ciertas confusas vacilaciones en las órdenes de Wall. Rodríguez Villa lo rebajó sin duda.

Sí hemos analizado la biblioteca ${ }^{36}$ del marqués inventariada igualmente por orden de Wall, que Rodríguez Villa no transcribió. Sólo citó el número de libros, en este caso un número muy superior a los que realmente hay en el inventario. La biblioteca es realmente interesante, pero lo es igualmente la de Ordeñana, mucho más amplia, y la de Mogrovejo, más reducida pero muy interesante porque se anotan sus manuscritos, sobre todo las cartas. Estas últimas nos han ayudado a describir las amplias relaciones que tenía este incondicional ensenadista.También la de Macanaz tiene un enorme interés, aunque no existe un inventario sino datos sueltos procedentes de los lugares por donde iban pasando sus baules ${ }^{37}$.

Es también de gran interés el análisis de la legislación emanada del ministerio de Ensenada; tanto las colecciones de leyes, como los libros del Ministerio de Hacienda depositados en AHN son las primeras fuentes. Pero, además, muchas de estas leyes, sobre todo las que siguen al gran despliegue de 1749 fueron difundidas por el propio Ensenada en las embajadas europeas en un momento de gran euforia que intentó transmitir mediante cartas con comentarios sobre sus pretensiones y alcance de las leyes, que le eran respondidas con opiniones elogiosas. Estos comentarios tienen un interés extraordinario, pues el marqués justifica su política con más claridad que la que aportan los textos oficiales. El mismo interés tienen las cartas en que Ensenada solicita a los embajadores información sobre

35. AHN, Estado, leg. 5048. Hemos trabajado el inventario aunque no lo hemos utilizado en nuestro El marqués... Reservamos el proceso de la caída y la actuación de Wall contra los ensenadistas durante los diez días siguientes a una próxima publicación. Con todo, hablamos a menudo del problema de la riqueza de Ensenada, sólo que no la tomamos como un dato aislado, sino como un problema general que atañe a la confusión de fondos en las haciendas del Antiguo Régimen. $C f r$. Dessert, M.,1984. El posible instrumento del giro real como medio de enriquecimiento, del que sospechamos, exige nuevas fuentes, que, por el momento, no hemos localizado.

36. Vid. apéndice en Gómez Urdáñez, J.L., 1996 e.p.

37. Véase García Gómez, M.D., 1990.. En nuestro trabajo aportamos otros libros procedentes de Breda; sólo hemos anotado los más comprometedores, sin duda, aquellos que tratan sobre la Inquisición y que están manuscritos, en los que también repararon más sus captores. Reservamos también parte de la documentación y otras fuentes seleccionadas para una próxima publicación. 
cómo han tratado las cortes europeas algunos asuntos que le preocupan. No sólo las interesantísimas instrucciones que da a Ulloa y a Jorge Juan arrojan luz sobre sus intereses y su disposición a adoptar soluciones probadas en Europa. Por ejemplo, la correspondencia que mantiene con Sotomayor, el embajador en Lisboa, conservada en AGS y AHN y utilizada sólo en parte en nuestro trabajo, deja entrever los planes del marqués para resolver la "cuestión gitana". Ensenada le pide información sobre la forma en que Portugal ha acabado con lo que el consideraba irrecuperable "mala raza", demostrando hasta dónde llegaban sus ideas francamente bárbaras sobre el asunto. Como a Sotomayor, pide a Masones ideas sobre los hospicios y hospitales; a Wall, sobre los aranceles fijados en los puertos británicos para equiparar con ellos los que el pensaba imponer, etc.

En una primera fase del trabajo se considera, pues, como prioridad en cuanto al acopio de fuentes, la crítica histórica de las habitualmente utilizadas y la fundamentación por el propio Ensenada de su obra legislativa y de su actuación política, así como la selección de fuentes que contribuyan al conocimiento del marco político, nacional e internacional, en el que se desenvolvió su ministerio. En este sentido, es importante continuar la investigación sobre el periodo 17461748, entre el cambio de corte y la paz de Aquisgrán, cuyas claves sólo hemos esbozado. Buena parte de la polémica sobre el improbable "partido castizo", sobre las divergencias entre Carvajal y Ensenada y sus proyectos de política exterior y sobre las dificultades del régimen ministerial y sus avances, están en estos años "preparatorios" de la coyuntura positiva posterior.

Interesa también analizar la documentación conservada en BN, no sólo por el interés general que subyace en los papeles anónimos, pasquines y versos que salieron después de julio, exhaustivamente explotados por T. Egido en su conocida obra. También porque hay otros documentos conservados de gran interés. El proyecto de Banfi y otros ensenadistas sobre el palo de Campeche ${ }^{38}$ es un buen ejemplo. Pero, hay otros que inciden en el mejor conocimiento de la pantofilia del marqués, desde su labor en la cartografía hasta su interés por las excavaciones arqueológicas y por otros aspectos de la técnica ${ }^{39}$. En este sentido, en una segunda fase se hace preciso ampliar nuestro trabajo sobre los fundamentos técnicos del proyecto ensenadista, en el que hemos destacado la relación del marqués con Ulloa, Juan, Solano y otros militares, la política de pensiones en el extranjero, las captaciones de técnicos extranjeros y los métodos de perfeccionamiento científico de la construcción naval. La política de arsenales y de movilización del ejército es consustancial al proyecto de Ensenada, como hemos expuesto; sin embargo y aún contando con las aportaciones específicas de los especialistas en temas marineros y militares, es necesario continuar la investigación con el fin de profundizar

38. BN, mss., 1962-2. "Noticia de varios puntos... Método y práctica de cortar en la provincia de Yucatán o Campeche el palo de tinta".

39. Véase en la biblioteca de Ensenada, en el apéndice de nuestro trabajo, las obras que tratan de estos aspectos. Señalo, por poner algunos ejemplos, "Prodromo delle Antichitá d'Ercolano" o "Las ruinas de Palmira o meditación sobre las revoluciones de los Imperios". 
más, sobre todo, en el problema de las relaciones entre armada y comercio ultramarino, entre proyecto estatal y participación privada e ideas de reforma de las estructuras comerciales, probablemente la parte menos conocida del ministerio de Ensenada. En ese sentido, los fondos del Museo Naval, delArchivo de Indias y de los archivos provinciales de las ciudades portuarias españolas aportan datos de gran importancia para nuestro proyecto.

En suma, el proyecto "Ensenada" aspira a reforzar el conocimiento de un tiempo dominado por la acción reformista del ministro y a contribuir al debate historiográfico sobre el despotismo en España con nuevas aportaciones. Cuenta con soportes documentales suficientes $y$, en algunos aspectos, poco explorados, $\mathbf{y}$ con fundamentos teóricos que lo justifican. Pero, además, creemos que es nuestra concepción de la investigación histórica como labor de equipo el mejor seguro contra posibles desviaciones. Como en otros proyectos que anteriormente hemos dirigido, éste no es sólo la base de una publicación más. Antes que eso, pretende concitar la más amplia participación de investigadores, desde los jóvenes doctorandos hasta investigadores especializados. Y no sólo para "repartir" áreas de actuación, sino para conjugar en múltiples actividades, la labor de unos y otros, discutir, enseñar y aprender. El proyecto no acaba y empieza en la investigación. Como hicimos en el proyecto Historia de la Ciudad de Logroño, en el que la publicación final es sólo la última actividad, "Ensenada" es una plataforma de actuación global, en el marco de las actividades investigadoras, docentes y de impacto social externo de la Universidad de La Rioja.

Pretendemos involucrar en el proyecto todas las posibilidades que tanto la universidad como los poderes públicos pongan a nuestro alcance; siempre sin olvidar que nuestro instrumental son ante todo los hombres. Así, contamos ya con la participación de muchos dieciochistas consagrados -evidentemente, los primeros los que ya tienen una relación profesional con nosotros- en aspectos muy concretos que forman parte de su trabajo habitual, y con una serie de temas cuya elaboración encargamos a doctorandos de nuestro programa de doctorado del Dpto. de Ciencias Humanas y Sociales y a colaboradores de nuestro equipo estable de investigación en La Rioja ${ }^{40}$. Abriremos este marco de colaboración

40. Así, los doctores S. Ibáñez Rodríguez (UR) y P. Lorenzo Cadarso (U. de Extremadura) profundizarán sobre los problemas eclesiásticos en el tiempo de Ensenada y sobre el tema del poder y su representación externa en el caso del marqués, respectivamente. En este último aspecto la reciente publicación de P. Burke, La fabricación de Luis XIV. Madrid, 1995, ha abierto vías nuevas en cuanto a la utilización de materiales, que, en nuestro caso, podemos obtener de fuentes diversas, entre ellas el inventario del marqués o los papeles del Archivo de Palacio sobre los festivales del poder en Aranjuez. N. Armas, que ha trabajado sobre los problemas económicos del concejo logroñés, y $G$. Torrealba, sobre abastos, se proponen medir el efecto de la legislación ensenadista en los municipios y el papel que cumplió la ampliación de competencias de los intendentes y corregidores intentada por Ensenada, en varios casos concretos. J. R. Moreno Fernández (U. de Huelva), cuya investigación se orienta hacia los problemas ecológicos en los siglos XVIII y XIX (véase su reciente publicación, El monte público en La Rioja durante los siglos XVIII y XIX. Logroño, 1994), trabajará sobre la política de Ensenada sobre repoblación forestal, menos conocida que la de aprovechamiento de los bosques con destino a la marina, de donde le viene la fama de arboricida. 
todo lo posible. Pero, además, están los cauces de promoción científica. Como en el anterior proyecto, ésta se ha de realizar mediante reuniones científicas, ciclos de conferencias, un congreso preparatorio y uno internacional, éste en el año 2002, el III centenario del nacimiento de Zenón de Somodevilla; todo ello en el marco universitario, en torno a cursos de doctorado y relaciones interuniversitarias, las ya establecidas y las que se establezcan en el futuro. Pero, también con el apoyo de los poderes públicos -tanto regionales (no olvidamos aquí el origen riojano de Ensenada), como nacionales (no hará falta recordar que fue ministro de Hacienda, Marina, Guerra e Indias)-, que necesariamente habrán de responder en el año 2002 a la necesidad de un centenario con fundamento y rigor. 
EL PROYECTO POLÍTICO ENSENADISTA EN LA POLÉMICA SOBRE EL DESPOTISMO ILUSTRADO EN ESPAÑA

\section{BIBLIOGRAFÍA}

ABAD LEÓN, F.

El marqués de la Ensenada, su vida y su obra. Madrid, 1985.

ABBAD, F y OZANAM, D.

Les intendants espagnols du XVIII e siècle. Madrid, 1992.

ABELLÁN, J.L.

Historia crítica del pensamiento español. Del Barroco a la Ilustración. Madrid, 1981.

ACEDO CERDÁ, $M$.

El Real Cuerpo de Artillería de la Armada. Madrid, 1970.

AGUILAR PIÑAL, F.

«Sobre política cultural de Fernado VI», La época de Fernando VI. Oviedo, 1981, pp. 297-314.

AGUILAR PIÑAL, $\mathrm{F}$

Bibliografía de autores españoles del siglo XVIII, tomos I a V. Madrid, 19811989.

AGUILAR PIÑAL, $\mathbf{F}$.

La biblioteca de Jovellanos (1778). Madrid, 1984.

ALCALÁ-ZAMORA y QUEIPO DE LLANO, J.

Historia de una empresa siderúrgica española: los altos bornos de Liérganes y La Cavada. 1622-1834. Santander, 1974.

ALCALÁ-ZAMORA y QUEIPO DE LLANO, J.

«Evolución del tonelaje de la flota de vela española durante los siglos modernos». Estudios, Departamento de Historia Moderna. Universidad de Zaragoza (1975) pp. 177-224.

ALCARAZ GÓMEZ,J.F.

Jesuitas y reformismo. El Padre Francisco de Rávago (1747-1755), Valencia, 1995.

ALEGRE, J.M.

Las relaciones bispano-danesas en la primera mitad del siglo XVIII. Madrid, 1978.

ALEMAY PEIRO, A.

Juan Antonio Mayans y Siscar (1718-1801). Esplendor $y$ crisis de la Ilustración valenciana. Valencia, 1994.

ALMIRANTE, J.

Bibliografía militar de España. Madrid, 1876.

ALONSO CASTROVIEJO, J.J.

Problemática agraria, soclución burguesa, Logroño, 1750-1833. Logroño, 1991.

ALONSO SAN JOSÉ, J.

Estado crítico sobre las ideas de gobierno y administración del marqués de la Ensenada.Juegos florales de Valladolid. Valladolid, 1883.

ÁLVAREZ SANTALO, L.C.

«Economía y sociedad en el siglo XVIII». Historia de España, dirig. por A. Domínguez Ortiz, tomo VII, Barcelona, 1989. 
JOSÉ LUIS GÓMEZ URDÁÑEZ

ÁLVAREZ SANTALO, L.C.

«Restauración del prestigio: los instrumentos de fuerza y negociación». Historia de España, dirig. por A. Domínguez Ortiz, tomo VII, Barcelona, 1989.

ALZOLA MINONDO

Las obras públicas en España. Madrid, 1979.

AMEZUA Y MAYO, A.G. de.

Un modelo de Estadistas. El marqués de la Ensenada. Enseñanzas y Comentarios. Conferencia pronunciada en la Real Academia de Jurisprudencia el día 30 de marzo de 1917. Madrid, 1917.

ANDÚJAR CASTILLO, $\mathrm{F}$.

Los militares en la España del siglo XVIII. Un estudio social. Granada, 1991.

ANES, G.

Economía e Ilustración en la España del siglo XVIII. Barcelona, 1969.

ANES, G.

«La contribución de frutos civiles entre los proyectos de reforma tributaria en la España del siglo XVIII», Hacienda Pública Española 27 (1974), pp. 21-46.

ANES, G. ROJO, L.A. y TEDDE, P.

Historia económica y pensamiento social. Madrid, 1983.

ANTEQUERA, J.M.

Memorias del marqués de la Ensenada a Fernando VI. Madrid, 1884.

APPLEBY, J.O.,

Economic Thought and Ideology in Seventeentb-Century England. Princeton, 1978.

ARANDA, J.M ${ }^{\mathrm{a}}$.

El Marqués de la Ensenada. Estudios sobre su administración. Madrid, 1898.

ARGEMI, Ll. (comp.)

Agricultura e Ilustración. Madrid, 1988.

ARGEMI, Ll.

"Agronomía y revolución agraria en España (1750-1820)», Agronomía y fisiocracria. Valencia, 1985, pp. 1-44.

ARGUMOSA Y GÁNDARA,T.V.

Erudición politica: Despertador sobre el comercio, agricultura y manufacturas... Madrid, 1743.

ARTIÑANOY DE GALDANO, G.

La arquitectura naval epañola. (en madera). Madrid, 1920.

ARTOLA, M.

«Campillo y las reformas de Carlos III». Revista de Indias, XII (1952).

ARTOLA, M. y BILBAO, L.Ma .

Estudios de Hacienda de Ensenada a Mon. Madrid, 1984.

AZNAR, B.F.

Discurso que formó tocante a la Real bacienda. Madrid, 1727.

BARREDA, F.

La marina cántabra desde el siglo XVII al ocaso de la navegación a vela. Santander, 1968. 
EL PROYECTO POLÍTICO ENSENADISTA EN LA POLÉMICA SOBRE EL DESPOTISMO ILUSTRADO EN ESPAÑA

BARRENECHEA M.T.

«María Bárbara de Braganza, princesa de Asturias». Eidos, 4 (1956).

BARRIOS GUTIÉRREZ, J.

«La enseñanza de la Artillería en España, hasta el Colegio de Segovia». Revista de Historia Militar, 18.

BARRIOS, $\mathrm{F}$.

El Consejo de Estado de la monarquía española (1521-1812). Madrid, 1984.

BARROSO, M.

El Marqués de la Ensenada. Estudio crítico sobre las ideas de administración $y$ gobierno de tan insigne estadista. San Sebastián, 1887.

BAUER MANDERSCHEID, E.

Los montes de España en la Historia. Madrid, 1991.

BAUDRILLART, A.

Philippe V et la Cour de France. París, 1900.

BEDARIDA, $\mathrm{H}$.

Les premiers Bourbons de Parme et l'Espagne (1731-1802). París, 1928.

BERMEJO CABRERO, J.L.

Estudios sobre la administración central española (siglos XVII y XVIII). Madrid, 1982.

BERNARD, G.

«Liste des Secrétaires d'Etat espagnols de l'avènement des bourbons jusqu'en 1808», Revista de Archivos, Bibliotecas y Museos LXII, 2 (1956), pp. 387-394.

BERNARD, G.

Le Secrétariat d'Etat et le conseil espagnol des Indes, 1700-1808. Ginebra, 1972.

BETHENCOURT MASSIEU, A.

de, Patiño en la política internacional de Felipe V.Valladolid, 1954.

BETHENCOURT MASSIEU, A.

«El marqués de la Ensenada y la Arqueología». Boletín del Seminario de Estudios de Arte y Arqueología de Valladolid, 1963, pp. 73-88.

BERGIN, J.

Pouvoir et fortune de Richelieu, París, 1987.

BITAR LETAYF, $M$.

Economistas españoles del siglo XVIII. Madrid, 1968.

BLANCHARD, A.

Les ingenieurs du "Rey" de Louis XIV à Louis XVI. Montpellier, 1979.

BORREGUERO BELTRÁN, C.

El reclutamiento militar por quintas en la España del siglo XVIII. Orígenes del servicio militar obligatorio. Salamanca, 1989.

BOSHER, W.

The Spanish Colonial System. Cambridge, 1944.

BOUVIER, R. y SOLDEVILLA, C.

Ensenada et son temps. Le redressement de l'Espagne au XVIII siècle. París, 1941. 
BOUVIER, R.

Farinelli, le chanteur des rois. Paris, 1943.

CALLAHAN, WJ.

"A nota on the Real and General Junta de Comercio". Economic History Review, 1969.

CALLAHAN, W.J.

«La política económica y las manufacturas de estado en el siglo XVIII», Revista de Trabajo 38 (1972), pp. 5-17.

CALLAHAN, W.J.

Iglesia, poder y sociedad en España, 1750-1874. Madrid, 1989.

CAMARERO BULLÓN, C.

Burgos y el Catastro de Ensenada. Burgos, 1989.

CAMARERO BULLÓN, C.

El debate de la Unica Contribución. Catastrar las Castillas. 1749. Madrid, Alcabala del Viento, 1993.

CAMPILLO, J.

Nuevo sistema de gobierno económico para la América... Madrid, 1789.

CAMPILLO, J.

Lo que bay de más y de menos en España para que sea lo que debe ser y no lo que es [1741-1742]. Ed. y estudio preliminar de Antonio Elorza. Madrid, 1969. CANO REVORA, M.G.

Cádiz y el Real Cuerpo de Ingenieros Militares (1697-1847). Utilidad y firmeza. Cádiz, 1994.

CANTILLÓN, R.

Ensayo sobre la naturaleza del comercio en general (1755). Mexico, 1950.

CAPEL, H. y otros,

Los ingenieros militares en España. Siglo XVIII. Repertorio biográfico e inventario de su labor científica y espacial. Barcelona, 1968.

CAPEL, $\mathrm{H}$.

«La geografía como ciencia matemática mixta. La aportación del círculo jesuita madrileño en el XVIII». Geo-Crítica, 30 (1980).

CAPEL, $\mathrm{H}$.

Geografía y matemáticas en la España del siglo XVIII. Barcelona, 1982.

CAPEL, H.; SÁNCHEZ, J. y MONCADA, O.

De Palas a Minerva. La formación científica y la estructura institucional de los Ingenieros militares en el siglo XVIII. Barcelona, 1988.

Carlos III y la Ilustración. Madrid, 1988.

CARO BAROJA, J.

La hora navarra del siglo XVIII (Personas, familias, negocios e ideas). Pamplona, 1969.

CASO GONZÁLEZ, J.M.

y otros. La Ilustración Española. Madrid, 1985.

CASTANEDO GALÁN, J.M.

Guardizo, un astillero de la Corona. Madrid, 1993. 
EL PROYECTO POLÍTICO ENSENADISTA EN LA POLÉMICA SOBRE EL DESPOTISMO ILUSTRADO EN ESPAÑA

CASTELLANO, J.L.

«La sociedad del Antiguo Régimen y la concepción fiscal de la Ilustración». Hacienda Pública Española, 87 (1984), pp. 241-254.

CEPEDA ADÁN, J.

«El Ejército español en el siglo XVIII». Coloquio Internacional Carlos III y sze siglo. Tomo I. Madrid, 1990, pp. 557-564.

CHISICK, $\mathrm{H}$.

The limits of Reform in the Enlighetenment. Attitudes toward the Education of the Lower Classes in Eigteenth Century France. Princeton, 1981.

CIPOLLA, C.M.

«The economic policies of governement», The Italian and Iberian Peninsula, The Cambridge Economic Histori of Europe, III. Cambridge, 1965.

CIPOLLA, C.M.

Cañones y velas en la primera fase de la expansión europea, 1400-1700.

Barcelona, 1967.

COLMEIRO, M.

Historia de la economía política en España. Madrid, 1965.

COLLINS, J.B.

Fiscal limits of absolutism. Direct taxation in early Seventeenth-century France, Berkeley, 1988.

COXE, G.

España bajo el reinado de la casa de Borbón, desde 1700 en que subió al trono Felipe V, hasta la muerte de Carlos III, acaecida en 1788. Madrid, 1846. 4 vols.

CRAY WINCKEL, F.

«Discurso sobre el estado de la Agricultura y de las Artes en España» [1760].

CREMADES GRIÑÁN, C.M .

(ed.) Actas del I Symposium Internacional: Estado y Fiscalidad en el Antiguo Régimen. Murcia, 1988.

CUENCA TORIBIO, J.M.

«La política exterior de la España dieciochesca. Sus instrumentos: marina, ejército, diplomacia». Archivo Hispalense, $2^{a}$ época v. L-LI (1969), pp. 153-158.

CUESTA, N.

«La introducción en España del análisis infinitesimal». Boletín de la Sociedad Española de Historia de la Ciencia, 3 (1979).

DANVILA Y BURGUERO, A.

Estudios españoles del siglo XVIII. Fernando VI y doña Bárbara de Braganza. Madrid, 1905.

DELGADO RIBAS, J.M.

«Política ilustrada, industria española y mercado americano, 1720-1820)». Pedralbes, 3 (1983), pp. 253-263.

DEMERSON, J.

«Un aspecto de las relaciones hispano-francesas en tiempo de FernandoVI. Las "Memorias literarias de París" de Ignacio Luzán (1751)». La época de Fernando $V I$. Oviedo, 1981, pp. 241-274. 
JOSÉ LUIS GÓMEZ URDÁÑNZZ

DESDEVISSES DU DEZER, $G$.

«Le Conseil de Castille au XVIII siècle».Revue Històrique, 79 (1902), pp. 23-40 y 226-294.

DESDEVISSES DU DEZER, G.

«La chambre des juges de l'Hôtel et de la Cour en 1745». Revue Hispànique, 36 (1916), pp. 1-51.

DESDEVISSES DU DEZER, $G$.

«La Societé espagnole au XVIIIe siècle». Revue Hispanique, LXX (1927).

DESDEVISSES DU DEZER, $G$.

«Les Institutions de l'Espagne au XVIIIe siècle».Revue Hispanique, LXXX (1928).

DESDEVISSES DU DEZER, G.

La España del Antiguo Régimen, Madrid, 1989.

DOGHERTY, A.

«La Real Armada y el ejército en el siglo XVIII. La equiparación militar». Revista general de Marina, 1952, pp. 122

DOMÍNGUEZ ORTIZ, A.

Sociedad y Estado en el siglo XVIII español. Barcelona, 1976.

DOMÍNGUEZ ORTIZ, A.

Carlos III y la España de la Ilustración. Madrid, 1990.

DONÉZAR Y DÍAZ DE ULZURRUN, J.M.

Riqueza y propiedad en la Castilla del Antiguo Régimen. La provincia de Toledo en el siglo XVIII, Madrid, 1984.

DUFOUR, G.

El Fuero de la Conciencia o Diálogo entre un confesor y un penitente a propósito del Sexto Mandamieto, Alicante, 1994.

DUQUE DE ALBA,

El Duque de Huéscar. Apuntes biográficos según los documentos del arcbivo de la Casa de Alba. Madrid, 1946.

EGIDO, T.

Opinión pública y oposición al poder en la España del siglo XVIII (17391759), Valladolid, 1971.

EGIDO,T.

Sátiras políticas de la España Moderna. Madrid, 1973.

EGIDO, T. y CEJUDO, J.

Edición, introducción y notas al Dictamen Fiscal de expulsión de los jesuitas de España (1766-1767), de Pedro Rodríguez de Campomanes. Madrid, 1977.

EGIDO, T.

«El regalismo y las relaciones Iglesia-Estado en el siglo XVIII», Historia de la Iglesia en España, vol. IV. Madrid, 1978.

EGIDO, T. y PINEDO, E.

Las causas "gravísimas" y secretas de la expulsión de los jesuitas por Carlos III. Madrid, 1994.

EGIDO,T.

«La inventada heterodoxia del regalismo borbónico». Historia de la Iglesia en España. IV. La Iglesia en la España de los siglos XVII y XVIII. Madrid, 1979. 
EL PROYECTO POLÍTICO ENSENADISTA EN LA POLÉMICA SOBRE EL DESPOTISMO ILUSTRADO EN ESPAÑ̃A

EGRET, G.

Louis XV et l'oposition parlamentaire. París, 1970.

EGUIA RUIZ, S.J.P.C.

El Marqués de la Ensenada, según un confidente. Madrid, 1922.

El Catastro en España, 1714-1906. De los catastros del siglo XVIII a los Amillaramientos de la segunda mitad del siglo XIX. Vol. I. Madrid, 1984.

El comercio libre entre España y América Latina, 1765-1824. Madrid, 1984.

ENCISO RECIO, L.M.

Nipho y el periodismo español del siglo XVIII. Valladolid, 1956,

ENCISO, L.M.GONZÁLEZ, A.EGIDO,T.BARRIO, M. y TORRES, R.

Los Borbones en el siglo XVIII (1700-1808). Madrid, 1991.

ESCRIBANO, J.M.

Itinerario español o guía de caminos para ir de Madrid a todas las Ciudades $y$ villas más principales de España; y para ir de unas Ciudades a otras; $y$ a algunas Cortes de la Europa. Madrid, 1758.

ESCUDERO, J.A.

Los Secretarios de Estado y del Despacho, 1474-1724. Madrid, 1969.

ESCUDERO, J.A.

Los orígenes del Consejo de Ministros en España. La Junta Suprema de Estado. Madrid, 1979.

ESCUDERO, J.A.

«La reconstrucción de la administración central en el siglo XVIII». Historia de España de Ramón Menéndez Pidal, XXIX-1, Madrid, 1985, pp. 79-175.

ESPADAS BURGOS, $M$.

«Fernando VI o el reformismo pacífista». Anales del Instituto de Estudios Madrileños, III (1968), pp. 319-330.

FARTOS, M.

«La ilustración francesa y su difusión en España». Investigaciones bistóricas, 13, (1993).

FAYARD, J.

«Los ministros del Consejo Real de Castilla en la época moderna (1621-1746). En torno a una tesis doctoral». Boletín de la Real Academia de la Historia, tomo CLXXVI (1979), pp. 139-148.

FAYARD, $\mathrm{J}$.

«Los ministros del Consejo Real de Castilla (1621-1788), Informes biográficos». Hidalguía, 1980-82.

FAYARD, J.

"Los Ministros del Consejo Real de Castilla (1746-1788)», Cuadernos de Investigación Histórica, 6 (1982), pp. 109-136.

FAYARD, J.

Los miembros del Consejo de Castilla (1621-1746). Madrid, 1982.

FERNÁN NÚÑEZ,

Vida de Carlos III. Madrid, 1898.

FERNÁNDEZ, R. (ed.),

España en el siglo XVIII. Homenaje a Pierre Vilar. Barcelona, 1985 
JOSÉ LUIS GÓMEZ URDÁÑEZ

FERNÁNDEZ, R.

Manual de Historia de España. t. 4. La España Moderna, siglo XVIII. Madrid, 1993.

FERNÁNDEZ ALBADALEJO, $\mathbf{P}$.

«El decreto de suspensión de pagos de 1739. Análisis e Implicaciones», Moneda y Crédito 142 (1977), pp. 51-85.

FERNÁNDEZ MESA,T.

Tratado legal y político de los caminos públicos y posadas. Valencia, 1755.

FERNÁNDEZ DE NAVARRETE, M.

Noticia biográfica del Marqués de la Ensenada. Madrid, 1831.

FERNÁNDEZ DE PINEDO, E.

Centralismo, Ilustración y agonía del Antiguo Régimen (1715-1833), Historia de España, dirigida por M.Tuñón de Lara, Vol.VII, Barcelona,1980.

FERNÁNDEZ DE VELASCO, F.

«D. Juan Fernández de Isla. Sus empresas y sus fábricas». Revista de Archivos, Bibliotecas y Museos V (1901), pp.81-96, 217-233, 294-311 y 378-387.

FERNÁNDEZ DURO, C.

La Armada española desde la unión de los pueblos de Castilla y León. Madrid, 1895-1903.

FERNÁNDEZ ESPEJO, C. y MARTÍNEZ CARDOS, J.

Primera Secretaría de Estado. Ministerio de Estado. Disposiciones orgánicas (1705-1936). Madrid, 1972.

FERRANDIS, $M$.

«Equilibrio europeo de don José Carvajal y Lancaster». Revista bistórica (Valladolid), $2^{\mathrm{a}}$ época 1 (1924), pp. 157-163.

FERRER DEL RÍO, A.

Historia del reinado de Carlos III en España. Madrid, 1984.

FLANDES, L.

El antiguo académico contra el moderno escéptico o dudoso, rigido o moderado. Defensa de las ciencias y especialmente de la física pitagórica y médica en el conocimiento y práctica de los médicos sabios. Madrid, s.f.

FONTANA, J.

"El alimento del Estado. Política y hacienda en el "Despotismo Ilustrado"». Hacienda Pública Española, 108-109 (1987), pp. 157-168.

FONTANA, J.

"Estado y Hacienda en el Despotismo Ilustrado", en VV.AA.Estado, Hacienda $y$ Sociedad en la Historia de España, Valladolid, 1989, 125-147.

GÁRATE OJANGUREN, M.

La Real Compañía Guipuzcóana de Caracas. San Sebastián, 1990.

GARCÍA-BAQUERO GONZÁLEZ,

A.Cádiz y el Atlántico, 1717-1778. El comercio colonial español bajo el monopolio gaditano. Sevilla, 1976.

GARCÍA-BAQUERO GONZÁLEZ, A.

«La recuperación desde el atraso: política de fomento». Historia de España, dirig. por A. Domínguez Ortiz, tomo VII, Barcelona, 1989. 
EL PROYECTO POLÍTICO ENSENADISTA EN LA POLÉMICA SOBRE EL DESPOTISMO ILUSTRADO EN ESPAÑA

GARCÍA GÓMEZ, M.D.

«La biblioteca de Melchor de Macanaz: fuentes forales y regalistas». Coloquio Internacional Carlos III y su siglo. Tomo II. Madrid, 1990, pp. 275-298.

GARCÍA-LOMBARDERO, J.

"Algunos problemas de la adminsitración y cobranza de las rentas provinciales en la primera mitad del siglo XVIII». Dinero y Crédito (siglos XVI al XIX), $A$. OTAZU (ed.), Madrid, 1978, pp. 63-88.

GARCÍA PELAYO, M.

«El estamento de la nobleza en el despotismo ilustrado español». Moneda $\mathcal{y}$ Crédito, 17, junio 1946.

GARCÍA RIVES, A.

Fernando VI y $D^{a}$ Bárbara de Braganza. Apuntes sobre su reinado (17461759). Madrid, 1917.

GARZÓN PAREJA, M.

Historia de la Hacienda de España. Madrid, 1984.

GAUDEAU, B.

Etude sur "Fray Gerundio"et son auteur, le P.José Francisco de Isla, 1703-1781. Paris, 1890.

GIL OSSORIO, F.

Organización de la artillería española en el siglo XVIII. Madrid, 1981.

GIMÉNEZ LÓPEZ, E.

Militares en Valencia (1707-1808). Los instrumentos del poder borbónico entre la Nueva Planta y la crisis del Antiguo Régimen. Alicante, 1990.

GÓMEZ ALFARO, A.

La Gran Redada de Gitanos. España: la prisión general de Gitanos de 1749. Madrid, 1993.

GÓMEZ DEL CAMPILLO, M.

«El Espía Mayor y el Conductor de Embajadas». Boletín de la Real Academia de la Historia, tomo CXIX (1946).

GÓMEZ MOLLEDA, M.A.

Una contienda diplomática en el reinado de Felipe V. Madrid, 1953.

GÓMEZ MOLLEDA, M.D.

«El pensamiento de don José Carvajal y Lancáster en la política internacional española del siglo XVIII. Utopía y realismo de una política». Arbor, (febrero 1954).

GÓMEZ MOLLEDA, M.D.

«El pensamiento de Carvajal y la política internacional española del siglo XVIII». Hispania, 15 (1955), pp. 117-137.

GÓMEZ MOLLEDA, M.D.

«El marqués de la Ensenada a través de su correspondencia íntima». Eidos, 2, 1955, pp. 48-90.

GÓMEZ MOLLEDA, M.D.,

«Viejo y nuevo estilo político en la Corte de Fernando VI».Eidos, 6 (1957).

GÓMEZ MOLLEDA, M.D.

«El "caso Macanaz" en el congreso de Breda». Hispania, 18 (1958), pp. 62-128. 
JOSÉ LUIS GÓMEZ URDÁÑEZ

GÓMEZ MOLLEDA, M.D.

«Un rey sin gusto de mandar». Eidos, 8 ((enero-junio 1958), pp. 59-77.

GÓMEZ URDÁÑEZ, J.L.

et al.Textos y Documentos. Historia de España dirig. por M.Tuñón de Lara,t. XII, Barcelona, 1984.

GÓMEZ URDÁÑEZ, J.L. y LORENZO CADARSO, P.

"Las comunidades rurales frente al Estado absoluto», Melanges de la Casa de Velázquez, XXIX, 1993, pp. 79-92.

GÓMEZ URDÁÑEZ, J.L.

«El artificio temporal y su responsabilidad en la reconstrucción histórica: la tópica periodización del XVIII español». Lieux dits, Saint Etienne, 1995.

GONZÁlEZ DE AMEZUA, A.

«Un modelo de estadistas: el marqués de la Ensenada». Opúsculos Históricos Literarios, T. III, Madrid, 1951, pp. 21-66.

GONZÁLEZ ENCISO, A.

«La historiografia sobre la industria textil y el comercio exterior del siglo XVIII». Coloquio Internacional Carlos III y su siglo. Tomo I. Madrid, 1990, pp. 191-233.

GONZÁLEZ GONZÁLEZ, A.

La realidad económica guipuzcoana en los años de superación de la crisis económica del siglo XVII (1680-1730). San Sebastián, 1994.

GOUBERT, P.

El Antiguo Régimen, 2. Los poderes. Madrid, 1979.

GRICE-HUTCHINSON, M.

El pensamiento económico en España (1177-1740). Barcelona, 1982.

GUERRA, R.

La corte española del siglo XVIII. Madrid, 1991.

GUERRERO, A.C.

Viajeros británicos en la España del siglo XVIII. Madrid, 1990.

GUIARD,T.

La industria naval vizcaína. Anotaciones bistóricas y estadísticas, desde sus orígenes hasta 1927. Bilbao, 1968.

GUILLÉN TATO, J.F.

«Don Jorge Juan y la construcción naval». Revista General de Marina, 2 (1943), pp. 361-370.

GUILLÉN TATO, J.F.

La Naútica española en el siglo XVIII. Madrid, 1935.

GUILLÉNTATO, J.F.

"Juan y Ulloa y los precedentes del XVIII de la Real Academia de Ciencias de Madrid». Revista de la Real Academia de Ciencias Exactas, Físicas y Naturales de Madrid, vol. 34, pp. 440-461.

GUILLÉN TATO, J.F.

Los tenientes de Navío Jorge Juan y Santacilla y Antonio de Ulloa y de la TorreGuiral y la medición del Meridiano. Madrid, 1973. 
EL PROYECTO POLÍTICO ENSENADISTA EN LA POLÉMICA SOBRE EL DESPOTISMO ILUSTRADO EN ESPAÑA

GUINARD, P.J.

La Presse Espagnole de 1737 à 1791: formation et signification d'un genre. Centre de Recherches Hispaniques, París, 1973.

HAMILTON, E.J.

«Plans for a National Banck in Spain, 1701-1783». The journal of political Economy, 57 (1949), pp. 315-336.

HELGUERA QUIJANA, J.

«La invención del procedimiento de fundición de Artillería en sólido y su recepción en España a mediados del siglo XVIII». Temas de Historia Militar. Zaragoza, 1983.

HELGUERA QUIJANA, J.

"Las misiones de espionaje industrial en la época del Marqués de la Ensenada y su contribución al conocimiento de las nuevas técnicas metalúrgicas y artilleras a mediados del siglo XVIII. Estudios sobre bistoria de la Ciencia y de la Técnica. Valladolid, 1988, vol. II.

HELGUERA QUIJADA, J.

«Aproximación a la historia del Canal de Castilla». El Canal de Castilla. Madrid, 1986, pp. 59-162.

HELLWEGE, J.

Die Spanischen Provinzialmilizen im 18. Boppard am Rheim, H. Boldt, 1969.

HERNÁNDEZ ANDREU, J.

«La única contribución del marqués de la Ensenada y el impuesto único de la escuela fisiocrática». Moneda y Crédito, 117 (1971).

HERNÁNDEZ-SÁNCHEZ BARBA, M. (Dir.),

Historia de las Fuerzas Armadas. Madrid, 1983-84.

HERRERO FERNÁNDEZ-QUESADA, D.

Ciencia y Milicia en el siglo XVIII. Tomás de Mola, artillero ilustrado. (publicada por el Patronato del Alcazar de Segovia-Tesis Complutense).

HUETZ DE LEMPS, A.

Vignobles et vins du Nord-Ouest de l'Espagne. Bordeaux, 1967.

HUSSEY, R.

The Caracas Company, 1728-1784. Cambridge, 1934.

IBÁÑEZ DE IBERO, C.

El marqués de la Ensenada. Cádiz, 1941.

IBÁÑEZ DE IBERO, C.

«El marqués de la Ensenada y su política exterior». Revista de historia militar, 9 (1965), pp. 143-146.

IBÁÑEZ MOLINA, M.

"Una visión retrospectiva sobre las intendencias de 1718: la del marqués de Uztariz en 1748». Cuadernos de Investigación Histórica 10 (1986), pp. 153-163.

IBÁÑEZ RODRÍGUEZ, S.

Diezmo y primicia en la diócesis de Calaborra. Las fórmulas de participación eclesiástica en el producto agrario en La Rioja (siglos XVI al XVIII). Tesis doctoral. Universidad de La Rioja, 1995. 
IGLESIA GARCÍA, J.

Diez economistas españoles, siglos XVII-XVIII.K Madrid, 1992.

II Simposio de Historia de la Administración. Madrid, 1971.

IV Simposio de Historia de la Administración. Alcalá de Henares, 1984.

JADO CANALES, A.

«Don Juan Fernández de Isla y Alvear». Aportaciones al estudio de la bistoria económica de la Montaña. Santander, 1957.

JOVER, J.M.

Política mediterránea y política atlántica en la España de Feijóo. Oviedo, 1956.

KRATZ. G.

El tratado bispano-portugués de límites de 1750 y sus consecuencias. Roma, 1954.

LAFUENTE, A. y PESET, J.L.

«Política científica y espionaje industrial en los viajes de Jorge Juan y Antonio de Ulloa (1748-1751)». Melanges de la Casa de Velázquez, XVII (1981), pp. 233-262.

LAFUENTE, $M$.

Historia General de España, Madrid, 1857, t. XIX.

LAMADRID, R.S.

El concordato español de 1753 según los documentos originales de su negociación. Jerez de la Frontera, 1937.

Las Fuerzas Armadas españolas. Historia institucional y social. Madrid, 1986.

LEGUINA, E.

El P. Rávago, confesor de Fernando VI. Madrid, 1876.

LEONAR, L.G.

L'Armée et ses problèmes au XVIIIe siècle. París, 1858.

LODGE, R.

Studies in Eighteentb Century Diplomacy (1740-1748). Londres, 1930.

LODGE, R.

Private Correspondence of sir Benjamin Keene. Cambridge, 1933.

LÓPEZ, F.

«Aspectos específicos de la Ilustración española», II Simposio sobre el P. Feijóo y su siglo, Oviedo, 1981.

LÓPEZ CORDÓN, M.V.

"La primera secretaría de Estado: la institución, los hombres y su entorno (17141833)». Revista de la Universidad Complutense, 1980, pp. 15-44.

LÓPEZ CORDÓN, M.V.

«Bases institucionales y sociales de la acción exterior española en el siglo XVIII». Estado y fiscalidad en el Antiguo Régimen, Murcia, 1989.

LÓPEZ-CORDÓN CORTEZO, M.V.

Realidad e imagen de Europa en la España Ilustrada. Segovia, 1992.

LÓPEZ PIÑERO, J.M.

La introducción de la ciencia Moderna en España, Barcelona, 1969.

LOZANO IRUESTE, J.M ${ }^{\mathrm{a}}$.

La evolución de la hacienda central española. Madrid, 1970. 
EL PROYECTO POLÍTICO ENSENADISTA EN LA POLÉMICA SOBRE EL DESPOTISMO ILUSTRADO EN ESPAÑA

LUYNES, A.

Memoires du duc de Luynes sur la Cour de Louis XV, 1735-1758. París, 186065.

LYNCH, J.

El Siglo XVIII, Historia de España, dirig. por J. Lynch, t. XII, Barcelona, 1991.

LLOMBART, V.

«A propósito de los intentos de reforma de la Hacienda castellana en el siglo XVIII: Campomanes frente al proyecto de Unica Contribución». Hacienda Pública Española 38 (1976), pp. 123-132.

LLUCH, E. y ARGEMI, Ll.

Agronomía y fisiocaracia en España (21750-1820). Valencia, 1985.

MACANAZ, M.

Carta y diseño para que un Primer Ministro o Secretario lo sea con perfección.En Semanario Erudito de Valladares, VII, pp. 132-138.

MACANAZ, M.

Representación que bice y remití desde Lieja al señor Rey Don Felipe Quinto, expresando los notorios males que causan la despoblación de España y otros daños sumamente atendibles $y$ dignos de reparo; con los generales advertimentos para su universal remedio. En Semanario erudito de Valladares (1783), VIII, pp. 154-204.

MACANAZ, M.

Testamento político. Pedimento fiscal (Ed. de Joaquín Maldonado Macanaz). Madrid, 1972.

MADRAZO, S.

El sistema de comunicaciones en España, 1750-1850. Madrid, 1984.

MARAVALL, J.A.

"Las tendencias de reforma política en el siglo XVIII español». Revista de Occidente, XIX (segunda época) (1967), pp. 2-82.

MARAVALL, J.A.

Estudios de la bistoria del pensamiento español (siglo XVIII). Madrid, 1991.

MARAVALL, J.A.

«El Primer siglo XVIII y la obra de Feijóo», II Simposio, pp. 151-195.

MARCEL, G.

"Le géographe Tomas Lopez. Essai de biographie et de cartographie». Revue Hispanique, París, 16 (1907), pp. 137-143.

MARTÍN GAITE, C.

El proceso de Macanaz. Historia de un empapelamiento. Madrid, 1970.

MARTÍN GAITE, C.

Macanaz, otro paciente de la Inquisición. Madrid, 1975.

MARTÍNEZ CARDOS, J.

Primera secretaría de Estado. Ministerio de Estado. Disposiciones orgánicas (1705-1836). I. Madrid, 1972.

MARTÍNEZ ROBLES, $M$.

Los oficiales de las secretarias de la Corte bajo los Austrias y Borbones. Alcalá de Henares, 1987. 
MARTÍNEZ SHAW, C.

"Los orígenes de la industria algodonera catalana y en el comercio colonial", en Nadal, J. y Tortella, G. (eds.), Agricultura, comercio colonial y crecimiento económico en la España Contemporánea", Barcelona, 1973, pp. 243-267.

MARTÍNEZ SHAW, C.

Cataluña en la carrera de Indias, Barcelona, 1981.

MARTÍNEZ VALVERDE, C.

«Constitución y organización de la armada de Felipe V». Temas de historia militar I. Madrid, 1983, pp. 265-311.

MARTÍNEZ, $M$.

"Academias Militares de Matemáticas en el siglo XVIII. Coloquio Internacional Carlos III y su siglo. Tomo I. Madrid, 1990, pp. 601-617.

MATEOS DORADO, D.

«La Unica Contribución y el Catastro de Ensenada (1749-1759». La época de Fernando VI. Oviedo, 1981, pp. 227-240.

MATEOS DORADO, D.

«La actitud de Carlos III durante el año "sin rey" (1758-1759)». Actas del Congreso Internaciona sobre Carlos III y la Ilustración. Tomo I El Rey y la Monarquía. Madrid, 1989, pp. 299-321.

MATILLA TASCÓN, A.

La Unica Contribución y el Catastro del marqués de la Ensenada, Madrid, 1947.

MATILLA TASCÓN, A.

Historia de las minas de Almadén. Madrid, 1958.

MEIJIDE PARDO, A.

Economía marítima de la Galicia cantábrica en el siglo XVIII. Valladolid, 1971.

MELENDRERAS GIMENO, M.C.

Las campañas de Italia durante los años 1743-48. Murcia, 1987.

MERCADER I RIBAS, J.

Felipe V $i$ Catalunya. Barcelona, 1968.

MERCAPIDE COMPAINS, $\mathrm{N}$.

Crónica de Guarnizo y su Real Astillero. (Desde sus orígenes basta el año 1800). Santander, 1974.

MERINO NAVARRO, J.P.

«Cultivos industriales: el cáñamo en España, 1750-1800». Hispania, 131 (1975), pp. 567-584.

MERINO NAVARRO, J.P.

«Técnicas y arsenales en España y Francia hacia 1800». Investigaciones históricas, 2 (1980).

MERINO NAVARRO, J.P.

«Cartagena, el arsenal ilustrado del Mediterráneo español». Areas, I (1981).

MERINO NAVARRO, J.P.,

La Armada Española en el siglo XVIII. Madrid, 1981. 
EL PROYECTO POLÍTICO ENSENADISTA EN LA POLÉMICA SOBRE EL DESPOTISMO ILUSTRADO EN ESPAÑA

MERINO, L.

Estudio crítico sobre las "Noticias Secretas de América" y el Clero Colonial (1720-1765). Madrid, 1956.

MESTRE, A.

«La Historiografía española del siglo XVIII». Coloquio Internacional Carlos III $y$ su siglo. Tomo I. Madrid, 1990, pp. 21-60.

MESTRE, A.

«La imagen de España en el siglo XVIII: apologistas, críticas y detractores». Simposio sobre posibilidades y límites de una bistoriografía nacional. Madrid, 1983.

MESTRE, A.

Ilustración y reforma de la Iglesia. Pensamiento político-religioso de don Gregorio Mayans y Siscar (1699-1781). Valencia, 1968.

MESTRE, A.

Despotismo e Ilustración en España, Barcelona, 1976.

MESTRE, A.

La Ilustración, Madrid, 1993.

MEYER, Jean,

Colbert, Paris, 1981.

MIJARES PÉREZ, L.

«Programa político para América del marqués de la Ensenada». Revista de Historia de América, 81 (1976).

MOLAS RIBALTA, P. y otros,

Historia social de la Administración española. Estudios sobre los siglos XVII y XVIII. Barcelona, 1980.

MOLAS RIBALTA, $P$.

«El Estado y la Administración en la España de Carlos III». Coloquio Internacional Carlos III y su siglo. Tomo I. Madrid, 1990, pp. 521-556.

MOLAS RIBALTA, P.,

«Los Fiscales de la Cámara de Castilla». Cuadernos de Historia Moderna 14 (1993), pp. 11-28.

MORALES, C.

Carlos Broschi Farinelli: Fiestas Reales en el Reinado de Fernando VI. Madrid, 1972.

MORALES HERNÁNDEZ, J.L.

«Jorge Juan en Londres». Revista General de Marina. Madrid 184 (1973), pp. 663670 .

MORALES MOYA, A.

«Estado y nobleza en el siglo XVIII». Revista de la Universidad Complutense, 1983/1-4, pp. 173-185.

MORALES MOYA, A.

Poder político, economía e ideología en el siglo XVIII español: la posición de la nobleza.Madrid, 1983. 
JOSÉ LUIS GÓMEZ URDÁÑ̃EZ

MORALES MOYA, A.

«Política y Administración en la España del siglo XVIII. (Notas para una sociología histórica de la Administración Pública)». Revista de la Administración Pública, 105 (1984), pp. 1167-201.

MORALES MOYA, A.

Reflexiones sobre el Estado español del siglo XVIII. Madrid, 1987.

MORALES MOYA, A.

«La ideología de la Ilustración española». Revista de Estudios Políticos (nueva época), 59, enero-marzo 1988.

MORALES, J.L.

«La marina en la segunda mitad del siglo XVIII». Segundo centenario de ingeniería naval. Madrid, 1975.

MORENO FERNÁNDEZ, J.R.

El monte público en La Rioja en los siglos XVIII y XIX. Logroño, 1994.

MORINEAU, M.

Incroyables gazettes et fabuleux métaux. Les retours des trésors américains d'après les gazettes bollandaises (XVI-XVIII siècles). Cambridge, 1985.

MOZAS MESA, M.

D. José de Carvajal y Lancaster, ministro de Fernando VI. Apuntes de su vida y labor política. Jaén, 1924.

MUHLMANN, R.

Die Reorganisation der Spanischen Kriegsmarine im 18 Jabrhundert. ColoniaViena, 1975.

NAVASCUES Y BELTRAL, I.

«Semblanza de Don Zenón de Somodevilla, I marqués de la Ensenada».Hidalguía, XIV, $\mathrm{n}^{\circ} 76$ (1966), pp. 385-396.

Nobleza y Sociedad en España en la Edad Moderna, Oviedo, 1996

OCHAGAVÍA FERNÁNDEZ, D.

«Matrimonios en el siglo XVIII, con noticias inédtas del Marqués de la Ensenada». Berceo, 47 (1948), pp. 131-154; 48, pp. 269-292; 49, pp. 379-403; 50 (1959), pp. 25-44.

OCHAGAVÍA FERNÁNDEZ, D.

«Don Cenón de Somodevilla, I Marqués de la Ensenada».Berceo, 13 (1949), pp. 511-524.

O'DOGHERTY, P.

«Jorge Juan y la ciencia española en el siglo XVII». Revista General de Marina, (184 (1973), pp. 671-689.

O'DOGHERTY, P.

«La ciencia naval en el siglo XVIII». Ingeniería Naval, agosto 1973, pp. 383-391.

OLAECHEA, R.

Las relaciones hispano-romanas en la segunda mitad del XVII. La Agencia de Preces. Zaragoza, 1965.

OLAECHEA, $\mathrm{R}$.

«El anticolegialismo del gobierno de Carlos III», Cuadernos de Investigación, II2 (1976), pp. 53-90. 
EL PROYECTO POLÍTICO ENSENADISTA EN LA POLÉMICA SOBRE EL DESPOTISMO ILUSTRADO EN ESPAÑA

OLAECHEA, R.,

"Las relaciones de España con la Santa Sede en el siglo XVIII», Historia de Za Iglesia, tomo XXI. Valencia, 1977.

OLAECHEA, R.

«Política eclesiástica de Fernando VI», La época de Fernando VI. Oviedo, 1981, pp. 139-226.

OLAECHEA, R.

Viajeros españoles del XVIII en los balnerarios del alto Pirineo francés, Logroño, 1985.

OLAECHEA, R.

«La "Ilustración" y el destierro de la compañía de Jesús». La Compañía de Jesús en Alcalá de Henares, 1546-1989, Madrid, 1989.

ORELLANA, E.J.

Historia de la Marina de Guera española desde sus orígenes basta nuestros días. Barcelona s/f. 2 vols.

ORTEGA MEDINA, J.

El conflicto anglo-español por el dominio oceánico (siglos XVII-XVIII). México, 1981.

OTAZU, A.

La reforma fiscal de 1749-1779 en Extremadura. Madrid, 1978.

OZANAM, D.

«Un projet de mariage entre l'infante Maria Antonia, soeur de Fernando VI et le

Dauphin fils de Louis XV (1746)». Estudios de Historia Moderna, I (1956), pp. 129-177.

OZANAM, D.

La diplomacia de Fernando VI. Correspondencia reservada entre don José de Carvajal y el Duque de Huéscar, 1746-1749, Madrid, 1975.

OZANAM, D.

"Notas para un estudio de los presupuestos de la monarquía española a mediados del siglo XVIII», Dinero y Crédito. Siglos XVI al XIX. Madrid, 1978, pp. 49 62.

OZANAM, D.,

«Representación del marqués de la Ensenada a Fernando VI (1751)», Cuadernos de Investigación Histórica, 4 (1980), pp. 67-124.

OZANAM, D.

"La diplomacia de los primeros borbones (1714-1759)», Cuadernos de Investigación Histórica, 6 (1982), pp. 169-193.

OZANAM, D.,

«La política exterior de España en tiempo de Felipe V y Fernado VI». Historia de España de Ramón Menéndez Pidal, t. XXIX, vol. I. Madrid, 1985, pp. 443-699.

PALACIO ATARD, $\mathrm{V}$.

«Las embajadas de Abreu y Fuentes en Londres, 1754-1761». Simancas Valladolid I (1950), pp. 55-121.

PALACIO ATARD, $\mathrm{V}$.

El Tercer Pacto de Familia. Madrid, 1954. 
PALACIO ATARD, $\mathrm{V}$.

"La neutralidad vigilante y constructiva de Fernando VI». Hispania, 133 (1976), pp. 301-320.

PANDO VILLARROYA, J.L.

La administración en la armada española. Madrid, 1977.

PARES, R.

King George III and the Politicians. Londres, 1953.

PARKER,

Geoffrey, The military revolution. Military innovation and the rise of the West, 1500-1800, Cambridge, 1988.

PASTOR REY DE VIÑAS, P.

Historia de la Real Fábrica de Cristales de San Ildefonso durante la época de la Ilustración (1727-1810). Madrid, 1994.

PEREYRA, C. y PÉREZ BUSTAMANTE, C.

Correspondencia reservada e inédita del P. Francisco de Rávago, confesor de Fernando VI. Madrid, s.f.

PÉREZ BUSTAMANTE, C.

«El reinado de Fernando VI en el reformismo español del siglo XVIII». Revista de la Universidad de Madrid, III (1954).

PÉREZ ESTÉVEZ, R.M.

El problema de los vagos en la España del siglo XVIII. Madrid, 1976.

PÉREZ-MALLAINA BUENO, P.E.

Política naval española en el Atlántico, 1700-1715. Sevilla, 1982.

PÉREZ SAMPER, $M^{\mathrm{a} A}$.

«El rey y la Corte. Poder y ceremonia. Un ejemplo: el acceso al trono de Carlos III". Actas del Congreso Internaciona sobre Carlos III y la Ilustración. Tomo I El Rey y la Monarquía. Madrid, 1989, pp. 5551-568.

PÉREZ SAMPER, M.A.

Las monarquías del Absolutismo Ilustrado. Madrid, 1993.

PÉREZ SARRIÓN, G.

El canal Imperial y la navegación basta 1812. Zaragoza, 1975.

PLUMB, J.H.

Sir Robert Walpole. Londres, 1956-1960.

POMEAU, R.

L'Europe des lumières. Cosmopolitisme et unité européenne au XVIIIe siècle. París, 1966 ( $2^{\text {a }}$ edi. rev. París, 1991).

PRADELLS NADAL, J.

Diplomacia y Comercio. La expansión consular española en el siglo XVIII. Alicante, 1992.

PRADELLS Y BALDAQUI,

«Los archiveros de la primera secretaría de Estado (siglo XVIII)». Revista de la Historia Moderna. Anales de la Universidad de Alicante, 6-7 (1988), pp. 117 134.

RABANAL YUS, A.

Las Reales fundiciones españolas del siglo XVIII. Madrid, 1980. 
EL PROYECTO POLÍTICO ENSENADISTA EN LA POLÉMICA SOBRE EL DESPOTISMO ILUSTRADO EN ESPAÑA

REEDER, J.

«Bibliografia de traducciones, al castellano y catalán durante el siglo XVIII, de obras de pensamiento económico», Moneda y Crédito 126 (1973), pp. 57-77.

REEDER, $\mathrm{J}$.

«Economía e Ilustración en España: traducciones y traductores, 1717-1800». Moneda y Crédito, 147 (1978), pp. 47-70.

REPARAZ, G.

«Les études scientifiques et la géographie en Espagne au XVIII e siècle».Bulletin HIspanique, 1943.

RINGROSE, D.R.

Los transportes y el estancamiento económico de España (1750-1850). Madrid, 1972.

RISCO, A.

La Real Academia de Sta. Bárbara de Madrid (1730-1808). Naissance et formation d'une élite dans l'Espagne du XIIIe siècle. Toulouse, 1979.

RIVAS FABAL, J.E.

Historia de la infantería de Marina española. Madrid, 1970.

RODRÍGUEZ, A.J.

Carta respuesta a un ilustre prelado. Madrid, 1753.

RODRÍGUEZ, L.

Reforma e Ilustración en la España del XVIII, Pedro Rodríguez de Campomanes. Madrid, 1975.

RODRÍGUEZ CASADO, V.

"La política del reformismo de los primeros borbones en la Marina de guerra española». Anuario de Estudios Americanos, XXV (1968).

RODRÍGUEZ VILLA, A.

Don Cenón de Somodevilla, marqués de la Ensenada, Ensayo biográfico, Madrid, 1878.

RODRÍGUEZ VILLA, A.

Patiño y Campillo. Madrid, 1892.

RUIZ MARTÍN, F.

«La banca en España hasta 1782». La Banca en España. Una historia económica. Madrid, 1970, pp. 1-196.

SALVA RIERA, J.

El Marqués de la Ensenada. Madrid, 1942.

SALVADOR, A.

El Marqués de la Ensenada. Discurso premiado en los juegos florales del Ateneo logroñés. Logroño, 1885.

SAMBRICIO, C.

«La ordenación del territorio como utopía real en la España Ilustrada». El canal de Castilla, Madrid, 1986.

SAMOYAULT, J.P.

Les bureaux du Secrétariat d'Etat des Affaires Etrangères sous Louis XV. París, 1971. 
JOSÉ LUIS GÓMEZ URDÁÑNEZ

SÁNCHEZ AGESTA, L.

El pensamiento político del Despotismo Ilustrado, Sevilla, 1979.

SÁNCHEZ DONCEL, G.

Presencia de España en Orán (1509-1792). Toledo, 1991.

SÁNCHEZ ORTEGA, H.

Los gitanos españoles. El período borbónico. Madrid, 1977.

SÁNCHEZ ORTEGA, H.

Documentación selecta sobre la situación de los gitanos españoles en el siglo XVIII. Madrid, 1977.

SÁNCHEZ ORTEGA, $\mathrm{H}$.

«Las relaciones hispano-turcas en el siglo XVIII».Hispania 171 (1989), pp. 151195.

SÁNCHEZ-BLANCO PARODY, F.

Europa y el pensamiento español del siglo XVIII, Madrid, 1991.

SARRAILH, J.

La España ilustrada de la segunda mitad del siglo XVIII. Madrid, 1974.

SCHOP SOLER, A.M.

Un siglo de relaciones diplomáticas y comerciales entre España y Rusia, 17331833. Madrid, 1984.

SELLES, M.PESET, J.L.y LAFUENTE, A. (Comp.),

Carlos III y la ciencia de la Ilustración. Madrid, 1988.

SOMOZA, J.

El capón. Avila, 1977.

SOTTO Y MONTES, J.de

«El reclutamiento militar en España». Revista de Historia Militar, 16 (1964).

SOUBEYROUX, J.

Pauperisme et rapports sociaux au XVIII siècle. Lille, 1978, 2 vols.

SOUBEYROUX, $\mathrm{J}$.

«La Biblioteca de Campomanes: contexto cultural de un ilustrado». Actas del Séptimo Congreso de la Asociación Internacional de Hispanistas, t. II, Roma, 1982.

STIFFONI, G.

«Intelectuales, sociedad y Estado», Historia de España, dirig. por Menéndez Pidal, t. XXIX, Madrid, 1985.

SUÁREZ GRIMON, V.

Construcción naval y tráfico marítimo en Gran Canaria en la segunda mitad del siglo XVIII. Las Palmas de Gran Canaria, 1993.

TEDDE DE LORCA, $P$.

La economía española al final del Antiguo Régimen.II Manufacturas. Madrid, 1982.

URIARTE AYO, R.

Estructura, desarrollo y crisis de la siderurgia tradicional vizcaína, 1700 1840. Bilbao, 1988.

Historia de los caminos de España. Vol I. Hasta el siglo XIX. Madrid, 1990. 
EL PROYECTO POLIÍTICO ENSENADISTA EN LA POLÉMICA SOBRE EL DESPOTISMO ILUSTRADO EN ESPAÑA

URTEAGA, L.

La Tierra esquilmada: las ideas sobre conservación de la naturaleza en la cultura española del siglo XVIII. Barcelona, 1987.

UZTARIZ, G.

Theorica y Práctica de Comercio y de Marina. Madrid, 1724. Edición facsímil de Gabriel Franco. Madrid, 1968.

VALLE Y GARCÍA JALÓN, R.

«En relación con el primer Marqués de la Ensenada», en Boletín de la Institución Fernán González 205 (1985), Burgos, pp. 47-57.

VÁZQUEZ DE PRADA,V.

«Las rutas comerciales entre España y América en el siglo XVIII». Anuario de Estudios Americanos, XXV (1968), pp. 209-253.

VENTURI, F.

«Economistas y reformadores españoles e italianos del siglo XVIII», en F. ESTAPE (ed.). Textos olvidados. Madrid, 1973, pp. 201-252.

VERNET GINES, J. ,

Historia de la Ciencia española. Madrid, 1975.

VILAR, P.

Cataluña en la España moderna. Barcelona, 1978.

VILAR, P.

Hidalgos, amotinados y guerrilleros. Pueblos y poderes en la bistoria de España. Barcelona, 1982.

WALKER, G.J.

Política española y comercio colonial (1700-1789). Barcelona, 1979.

WARD, B.

Proyecto económico. Estudio preliminar de J.L. Castellano. Madrid, 1982.

WILSON, Ch.

«Gerónymo de Ustáriz, un fundamento intelecutal para el renacimiento económico español del siglo XVIII».Dinero y Crédito. Siglos XVI al XIX. Madrid, 1978, pp. 189-196.

ZAFRA O'TEYZA, J.

Fiscalidad y Antiguo Régimen. Las rentas provinciales del Reino de Granada (1746-1780). Sevilla, 1991.

ZAVALA Y AUÑÓN, M.

«Representación al Rey N. Señor D. Fhelipe V (que Dios guarde) dirigida al mas seguro aumento del Real Erario...K S.L. 1732». Miscelánea Económico-política o Discursos varios sobre el modo de aliviar los vasallos con aumento del Real Erario. Pamplona, 1749. 


\section{BIBLIOGRAFÍA CITADA}

ALONSO CASTROVIEJO, J.J. 1992

Problemática agraria, solución burguesa. Logroño, 1750-1833. Logroño.

ÁLVAREZ JUNCO, J. 1990

El emperador del Paralelo. Lerroux y la demagogia populista. Madrid.

BERGERON, L. y CHAUSSINAND-NOGARET, G. 1978

Grands notables du Premier Empire. Paris.

BONSON AVENTIN. 1994

Joaquín Maurín (1896-1937). El impulso moral de bacer política. Huesca. Prólogo de C. Forcadell.

BOURDIEU, P. 1986

"L'illusion biographique", Actes de la Recherche en Sciencies sociales, 62-63, 6972.

CAMARERO BULLÓN, C. 1989

Burgos y el catastro de Ensenada, Burgos.

DESSERT, M. 1984

Argent, pouvoir et société au Grand siècle. Paris.

FERRAROTI, F. 1991

La bistoria y lo cotidiano. Barcelona.

FONTANA, J. 1987

"El alimento del Estado. Política y Hacienda en el 'Despotismo Ilustrado'", $\mathrm{Ha}$ cienda Pública Española.

FONTANA, J. 1989

"Estado y Hacienda en el "despotismo ilustrado", VV.AA.Estado, Hacienda y sociedad en la Historia de España, Valladolid.

GALLEGO, E. 1987

"Flotante en la biografia", Revista de Occidente, 74-75.

GARCÍA GÓMEZ, M.D. 1990

«La biblioteca de Melchor de Macanaz: fuentes forales y regalistas». Coloquio Internacional Carlos III y su siglo. Tomo II. Madrid, 275-298.

GARCÍA-LOMBARDERO, J. 1978

"Algunos problemas de la administración y cobranza de las rentas provinciales en la primera mitad del siglo XVIII", Dinero y Crédito (siglos XVI al XIX). Madrid.

GÓMEZ MOLLEDA, M.D. 1955

"El marqués de la Ensenada a través de su correspondencia íntima", Eidos, 2.

GÓMEZ URDÁÑEZ, J.L. 1995

"El artificio temporal y su responsabilidad en la reconstrucción histórica: la tópica periodización del XVIII español”. Lieux dits, Saint Etienne, 1995, 325-255.

GÓMEZ URDÁÑEZ, J.L. 1996, e.p.

El marqués de la Ensenada. El proyecto ilustrado de un déspota, 1743-1754.

GOUBERT, P.1979

El Antiguo Régimen, Los poderes. Madrid. 
EL PROYECTO POLÍTICO ENSENADISTA EN LA POLÉMICA SOBRE EL DESPOTISMO ILUSTRADO EN ESPAÑA

IGLESIAS, C. 1996

"La nobleza ilustrada del siglo XVIII español. El conde de Aranda", Nobleza $y$ Sociedad en España en la Edad Moderna, Oviedo.

LEVI, G. 1989

"Les usages de la biographie", Annales, E.S.C.6.

LYNCH, J. 1991

El Siglo XVIII, Historia de España, dirig. por J. Lynch, t. XII. Barcelona.

LORENZO CADARSO, P.1996

Los conflcitos populares en Castilla en los siglos XVI y XVII, Madrid, S. XXI, e.p.

MORALES MOYA, A. 1987

"En torno al auge de la biografia" Revista de Occidente, 74-75.

MORENO FERNÁNDEZ, J. R. y GÓMEZ URDÁÑ̃Z, J.L. 1995

Logroño en el siglo XIX. Logroño.

OLAECHEA, R. 1981

«Política eclesiástica de Fernando VI», La época de Fernando VI. Oviedo, 139226.

OLAECHEA ALBISTUR, R. 1989

"La "Ilustración" y el destierro de la compañía de Jesús". La Compañía de Jesús en Alcalá de Henares, 1546-1989. Madrid.

PARKER, G. 1988

The military revolution. Military innovation and the rise of the West, 1500 1800. Cambridge.

PAYNE, S.G. 1992

Franco. El perfil de la Historia. Madrid.

RODRÍGUEZ, L.1975

Reforma e Ilustración en la España del XVIII, Pedro Rodríguez de Campomanes. Madrid.

RUSPOLI Y MORENES, E. 1996

"La aristocracia ante la crisis del Antiguo Régimen: Godoy", en Nobleza y Sociedad en España en la Edad Moderna, Oviedo. 
